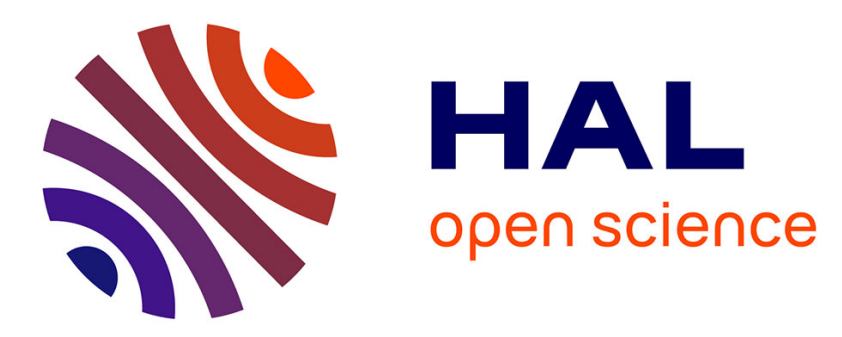

\title{
Biogeochemical cycles and aerosols over the last million years
}

\author{
Nathaëlle Bouttes, Laurent Bopp, Samuel Albani, Gilles Ramstein, Tristan \\ Vadsaria, Emilie Capron
}

\section{- To cite this version:}

Nathaëlle Bouttes, Laurent Bopp, Samuel Albani, Gilles Ramstein, Tristan Vadsaria, et al.. Biogeochemical cycles and aerosols over the last million years. Ramstein G.; Landais A.; Bouttes N.; Sepulchre P.; Govin A. Paleoclimatology, Springer, pp.271-300, 2021, Frontiers in Earth Sciences, 978-3-030-24982-3. hal-03027447

\section{HAL Id: hal-03027447 \\ https://hal.science/hal-03027447}

Submitted on 8 Nov 2021

HAL is a multi-disciplinary open access archive for the deposit and dissemination of scientific research documents, whether they are published or not. The documents may come from teaching and research institutions in France or abroad, or from public or private research centers.
L'archive ouverte pluridisciplinaire HAL, est destinée au dépôt et à la diffusion de documents scientifiques de niveau recherche, publiés ou non, émanant des établissements d'enseignement et de recherche français ou étrangers, des laboratoires publics ou privés. 


\title{
Chapter 2
}

\section{Biogeochemical cycles and aerosols over the last million years}

\author{
Nathaelle Bouttes, Laurent Bopp, Samuel Albani, Gilles Ramstein, Tristan Vadsaria, \\ Laboratoire des Sciences du Climat et de l'Environnement, LSCE/IPSL, CEA-CNRS-UVSQ, \\ Université Paris-Saclay, F-91191 Gif-sur-Yvette, France.
}

\section{Emilie Capron,}

British Antarctic Survey, High Cross, Madingley Road, Cambridge CB3 OET, UK.

Physics of Ice, Climate and Earth, Niels Bohr Institute, University of Copenhagen, Juliannes Maries Vej 30, 2100 Copenhagen Ø, Denmark.

\subsection{Introduction}

The biogeochemical cycles encompass the exchange of chemical elements between reservoirs such as the atmosphere, ocean, land and lithosphere. Those exchanges involve biological, geological and chemical processes, hence the term "biogeochemical cycles". A widely known cycle (which is not a biogeochemical cycle) is the water cycle, whose impact on climate is of major importance and which has been described in Volume 1 Chapter 1. Similarly, chemical elements such as carbon, nitrogen, oxygen and sulphur are also exchanged during cycles. Some of these elements can significantly impact climate through their effect on the atmospheric energy budget when they are in gaseous form $\left(\mathrm{CO}_{2}, \mathrm{CH}_{4}, \mathrm{~N}_{2} \mathrm{O}\right)$. The biogeochemical cycles are also affected by changes in climate, constituting a feedback in the Earth system. Other chemical compounds present in the atmosphere also influence the amount of energy available at the surface and therefore the dynamics of the climate: these are aerosols, small liquid or solid particles in suspension in the air. Because of the effect of climate on these chemical elements and particles, they sometimes record the changes that modified their cycle. It is possible to measure many of these tracers, which provide a valuable insight into past climate changes.

The link between the composition of the atmosphere and climate was discovered in the $19^{\text {th }}$ century through the work of Jean-Baptiste Fourier, a French mathematician. He showed that the Earth would be much colder than it currently is, if it was heated by incoming solar radiation alone. To explain the additional heating, he proposed, among other possibilities, that the Earth is insulated by gases present in the atmosphere. This effect of atmospheric gases blocking some of the infrared radiation emitted by the planet is now known as the greenhouse effect. Later, in 1860, John Tyndall, an English chemist, demonstrated that the two main constituents of our atmosphere, dinitrogen and dioxygen, are transparent to infrared radiation and therefore do not contribute to the greenhouse effect. On the other hand, he identified water vapour $\left(\mathrm{H}_{2} \mathrm{O}\right)$ and carbon dioxide $\left(\mathrm{CO}_{2}\right)$ as the two main greenhouse gases in our atmosphere. This led the way for another chemist, Svante Arrhenius, who, in 1896, was the first to estimate the change in the average temperature of the Earth's surface 
triggered by a change in the concentration of $\mathrm{CO}_{2}$ in the atmosphere. Lastly, it was only in the second half of the twentieth century that advances in measurement techniques made it possible to measure the impacts of other gases such as methane $\left(\mathrm{CH}_{4}\right)$, nitrous oxide $\left(\mathrm{N}_{2} \mathrm{O}\right)$, ozone $\left(\mathrm{O}_{3}\right)$, and chlorofluorocarbons (CFCs), on the greenhouse effect.

The direct effect of aerosols on climate was first suggested by Benjamin Franklin in the $18^{\text {th }}$ century to explain the cold winter of 1783-84. Benjamin Franklin noted there was a "constant fog over all Europe, and a great part of North America" which resulted in colder conditions. He suggested volcanic eruptions in Iceland as a possible explanation for this fog. Since then, the big volcanic eruptions that have occurred in the $19^{\text {th }}$ and $20^{\text {th }}$ centuries, such as the Krakatoa (1883), Santa Maria (1902), Katmai (1912), Agung (1963), El Chichon (1982) and Pinatubo (1991) have provided material to better understand the effects of aerosols that have recently been incorporated into climate models. The indirect effects of aerosols by modifying clouds were discovered more recently. The presence of aerosols can modify cloud characteristics by making them more reflective, or by extending their lifetime before precipitation, for example.

These chemical elements and aerosols are closely linked to climate and climate changes. Their concentration in the atmosphere impacts the Earth's energy budget, either directly or indirectly, while changes in climate modify the exchanges between reservoirs of these compounds and, in fine, their concentration in the atmosphere. Some atmospheric gases have the ability to modify the energy budget of the Earth (volume 1, chapter 1). The Earth receives shortwave radiation (ultraviolet, visible, and near-infrared) from the sun. Part of this radiation is reflected back by the surface, clouds and the atmosphere, part of it is absorbed by the atmosphere and clouds, and the last part is absorbed by the surface of the Earth. The Earth's surface emits longwave radiation (infrared) because it is colder than the sun, and also transfers energy to the atmosphere by latent and sensible heat. The longwave radiation from the Earth's surface is partly absorbed by the atmospheric greenhouse gases, which then re-emit radiation in all directions, including towards the surface of the Earth. The latter is then heated, resulting in a higher temperature than on an Earth without greenhouse gases. The radiation absorbed by the gases depends on their properties and in which zones they absorb radiation. Among the gases present in the atmosphere, the main greenhouse gases are, in decreasing order (excluding water vapor) carbon dioxide $\left(\mathrm{CO}_{2}\right)$, methane $\left(\mathrm{CH}_{4}\right)$ and nitrous oxide $\left(\mathrm{N}_{2} \mathrm{O}\right)$.

Aerosols have two effects on the energy budget in the atmosphere: direct and indirect. Aerosols are tiny particles - such as sea salt, dust from deserts and fires - in suspension in the atmosphere, either in liquid or solid form. They can absorb and disperse solar radiation, as well as absorb and emit thermal radiation. This is the direct effect. Aerosols also form cloud condensation nuclei and ice nuclei: raindrops and ice develop around these nuclei. This is the indirect effect because it modifies the energy budget through the modification of the microphysics of clouds. Depending on the size of the drops, which is dependent on the type and size of nuclei, the clouds will reflect or absorb radiation. In addition, aerosols deposited back to the surface will alter the amount of solar radiation reflected back to space, and will disperse chemical elements that can influence various biogeochemical cycles.

Some of the changes impacting on the biogeochemical cycles and aerosols are recorded and preserved for thousands of years. The main natural archives that have been used to track such changes are sediment cores extracted from oceans or lakes, and ice cores, drilled from polar ice sheets (Figure 1). 


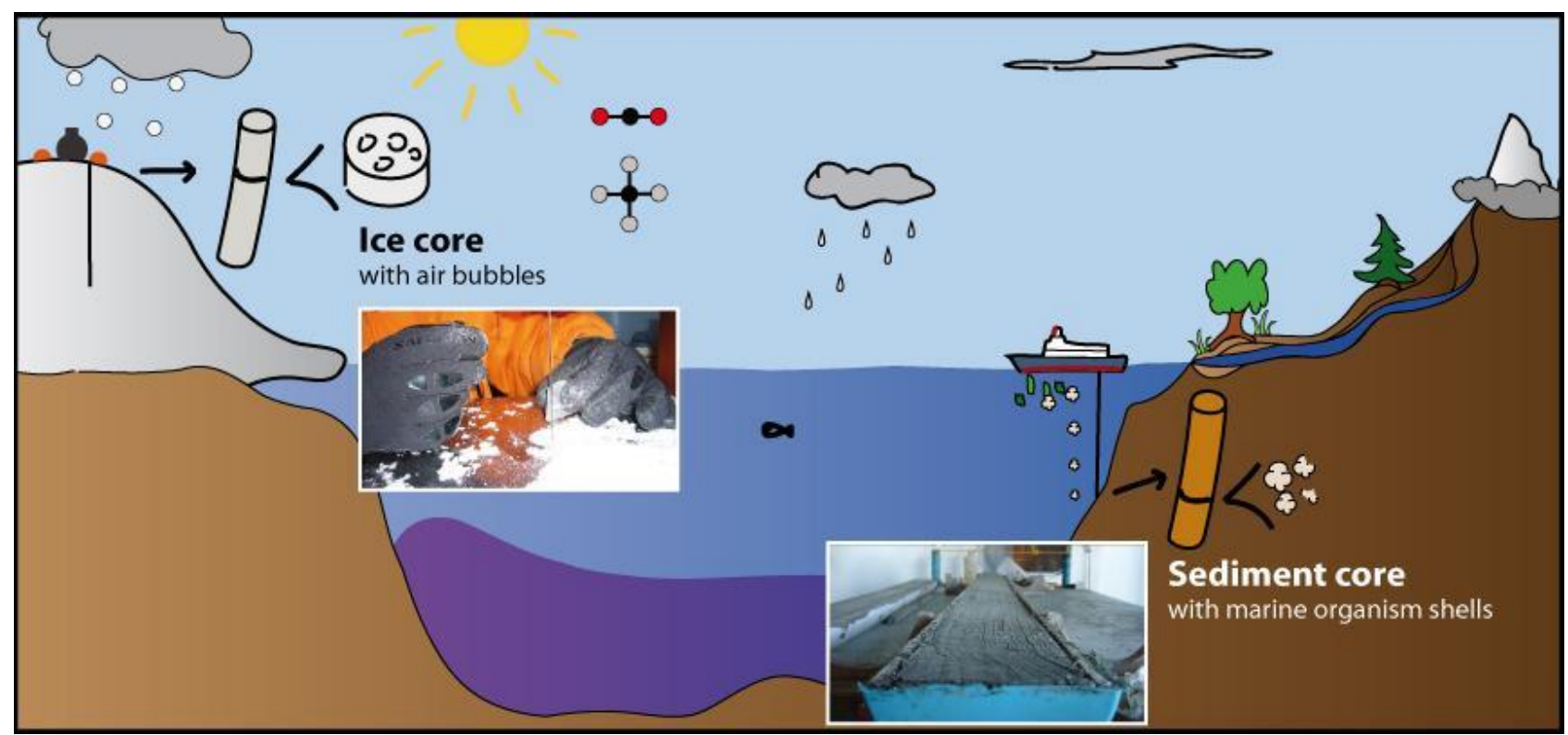

extraction.

Figure 1. Diagram of the Earth system and schemes showing ice cores and sediment cores

Marine sediment cores, collected from the bottom of the ocean, include various organic and inorganic elements, which can be used to get direct information. For example, examining the type of plankton that lived in a region at a given time can tell us how cold it was. A succession of species that thrive in warm or cold environments will indicate a succession of warm and cold periods. An analysis of the pollen present in sediment will yield information on the proportion of the major plants that lived on the nearby continent. In addition, the material is measured to obtain the ratio of chemical elements such as $\mathrm{Pa} / \mathrm{Th}$, and the ratio of isotopes such as oxygen and carbon isotopes $\left(\delta^{18} \mathrm{O}, \delta^{13} \mathrm{C}, \Delta^{14} \mathrm{C}\right)$, which can be used as indicators of specific processes such as ocean circulation changes, temperature changes, terrestrial biosphere changes, etc. (see volume 1, chapter 21).

The idea that ice from ice sheets could be used to provide information on past changes originated in the 1950's with the work of Willi Dansgaard and others, who hypothesized that the link between temperature and the number of heavy oxygen isotopes in precipitation could be applied to old ice to reconstruct past temperature changes. Ice core drilling began in Antarctica, Alaska and Greenland in the 1950's, but these cores were around $100 \mathrm{~m}$ deep and the recovery quality was low. Drilling to extract ice cores was spurred by the International Geophysical Year (1957-1958) and longer ice cores were drilled in Greenland at Site 2 (1956-1957) and in Antarctica at Byrd station (1957-1958) and at Little America V (1958-1959). Many more ice cores have been drilled since then, mainly in Greenland and Antarctica. Past climate and environmental changes are recorded both in the ice and in air bubbles trapped within the ice of the ice cores. For instance, the proportion of hydrogen and oxygen isotopes in the ice provide information on past surface temperatures, while the concentration of greenhouse gases can be directly measured in the air bubbles.

To understand the changes recorded in climate archives and to test various hypotheses on feedback mechanisms, more and more climate models now include biogeochemical cycles, and sometimes isotopes (see volume 2, chapters 4 and 8). Additional mechanisms and elements are added progressively so that simulations and measured data can be compared directly. This continuous comparison helps to increase our knowledge of the climate system resulting in improved models that can be used to evaluate possible future changes. These coupled carbon-climate models are valuable tools to help understand past changes and increase our confidence in future climate projections. 
In this chapter we describe the main biogeochemical cycles interacting with the climate: carbon $\left(\mathrm{CO}_{2}\right.$ and $\left.\mathrm{CH}_{4}\right)$, nitrogen, oxygen, sulphur, as well as aerosols. We review existing records from marine sediment cores and ice cores and highlight the current knowns and unknowns.

\subsection{Carbon cycle}

Two atmospheric gases containing carbon play a major role in the interactions between climate and biogeochemistry: carbon dioxide $\left(\mathrm{CO}_{2}\right)$ and methane $\left(\mathrm{CH}_{4}\right)$. While $\mathrm{CO}_{2}$ is the most famous and most studied element, $\mathrm{CH}_{4}$ is far from negligible and has a rather different cycle. We will first focus on $\mathrm{CO}_{2}$, then on $\mathrm{CH}_{4}$, before reviewing past changes.

\subsubsection{Carbon dioxide $\left(\mathrm{CO}_{2}\right)$}

On the timescale of a few hundred to a few tens of thousands of years, the main carbon reservoirs are the ocean (including sediments), atmosphere and land (including terrestrial biosphere and permafrost) (Figure 2). On the longer timescale of a few million years the lithosphere (rocks) starts to play a major role (see volume 1 chapter 2, volume 2 chapters 1 and 5). Exchanges between these reservoirs involve biotic processes, due to biological activity such as photosynthesis by plants, and abiotic processes.

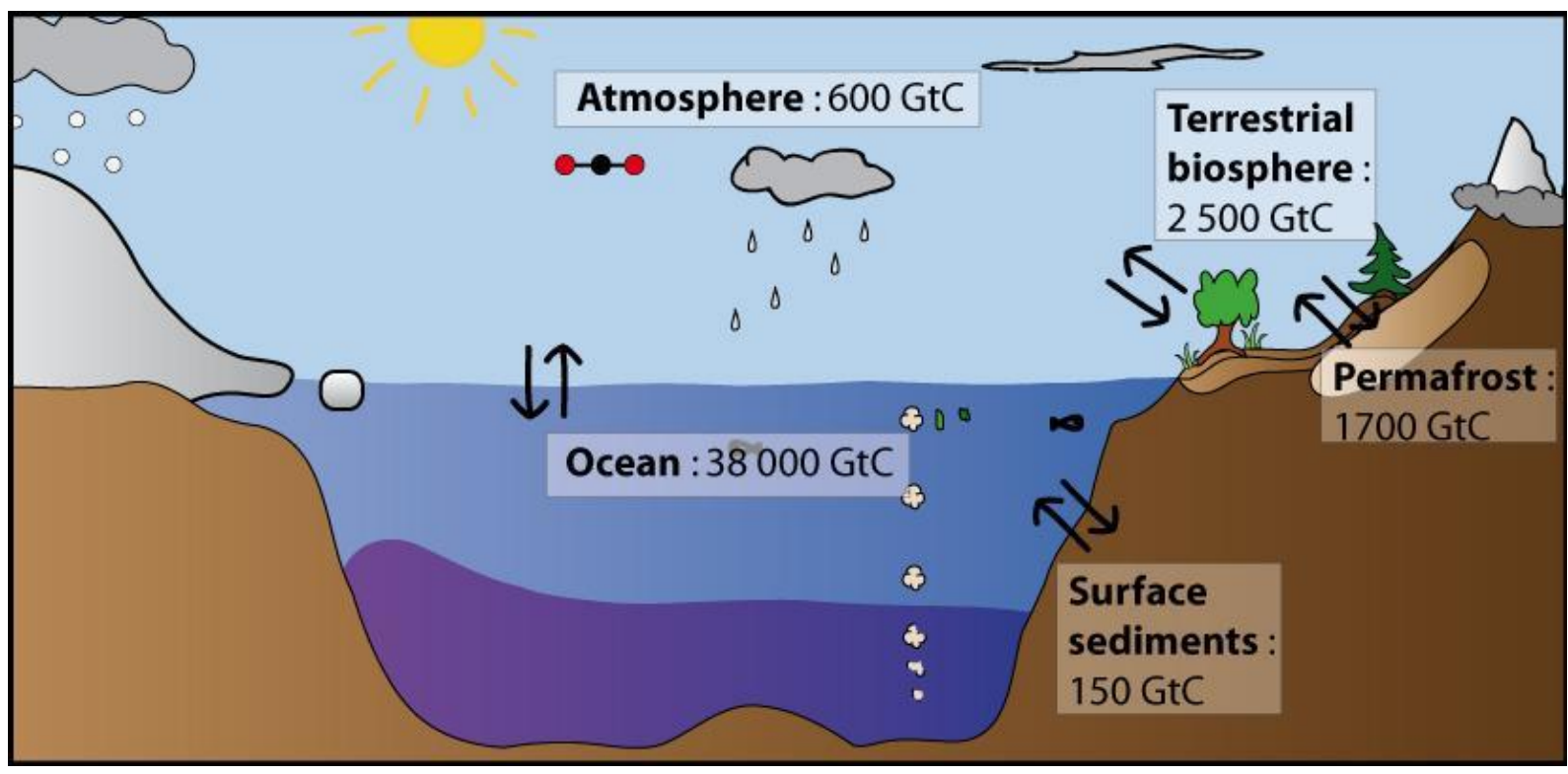

Figure 2. Diagram of the short term carbon cycle (up to a few tens of thousands years).

In the atmosphere, $\mathrm{CO}_{2}$ is the main form of carbon and is relatively well mixed over a year. Its concentration is currently increasing due to anthropogenic activity and, at the beginning of 2018, the atmospheric $\mathrm{CO}_{2}$ concentration was over 400 ppm (408 in March 2018, NOAA, https://www.esrl.noaa.gov/gmd/ccgg/trends/monthly.html). At the beginning of the pre-industrial era, it was around $280 \mathrm{ppm}$, corresponding to a carbon stock of around $600 \mathrm{GtC}$.

On land, atmospheric $\mathrm{CO}_{2}$ is taken up by plants during photosynthesis, turning $\mathrm{CO}_{2}$ into organic carbon. The living biomass is then converted into dead organic carbon matter in litter and soils. Organic carbon is progressively returned to the atmosphere by autotrophic and heterotrophic respiration. Currently, carbon storage in the terrestrial biosphere is around $2500 \mathrm{GtC}$. If the 
conditions become cold enough, the soil freezes, locking the carbon into permafrost, i.e. frozen soil. During warming, the permafrost thaws, and carbon is returned to the atmosphere. The current estimate of carbon stored in permafrost is $~ 1700 \mathrm{GtC}$ (Tarnocai et al., 2009), making it the single largest component of the terrestrial carbon pool. The fluxes of carbon between the atmosphere and land are around $120 \mathrm{GtC} /$ year.

The ocean is the largest carbon reservoir (excluding the lithosphere) with around 38,000 $\mathrm{GtC}$ both in organic and inorganic forms. Carbon fluxes to the ocean come from the atmosphere through surface exchanges and from the continent from riverine inputs. In the ocean, dissolved carbon $\left(\mathrm{CO}_{2}\right.$ (aq) ) gets hydrated into $\mathrm{H}_{2} \mathrm{CO}_{3}$ (carbonic acid), which then gives bicarbonate ion (or hydrogen carbonate ion, $\mathrm{HCO}_{3}{ }^{-}$) and carbonate ion $\mathrm{CO}_{3}{ }^{2-}$. All these dissolved species are summed up in the term "dissolved inorganic carbon" (DIC). Because the concentration of $\mathrm{H}_{2} \mathrm{CO}_{3}$ is very small, it is included in $\mathrm{CO}_{2(\mathrm{aq})}$. $\mathrm{CO}_{2(\mathrm{aq})}, \mathrm{HCO}_{3}{ }^{-}$and $\mathrm{CO}_{3}{ }^{2-}$ are in equilibrium following the chemical equations:

$$
\begin{gathered}
\mathrm{CO}_{2(a q)}+\mathrm{H}_{2} \mathrm{O} \rightleftarrows \mathrm{HCO}_{3}^{-}+\mathrm{H}^{+} \\
\mathrm{HCO}_{3}^{-} \rightleftarrows \mathrm{CO}_{3}^{2-}+\mathrm{H}^{+}
\end{gathered}
$$

$\mathrm{CO}_{2}$ is exchanged between the atmosphere and the surface ocean depending on the difference in partial pressure of $\mathrm{CO}_{2}\left(\mathrm{pCO}_{2}\right)$ between the atmosphere and ocean, on sea ice coverage and on wind. The $\mathrm{pCO}_{2}$ in the ocean is governed by temperature and salinity. The flux of carbon between atmosphere and dissolved inorganic carbon is around $70 \mathrm{GtC} /$ year in both directions.

In polar regions, $\mathrm{CO}_{2}$ is more soluble in water because of the colder conditions, resulting in more dissolved inorganic carbon in the surface ocean. These regions are also major sites of deep convection, where surface water becomes denser due to colder and more saline conditions, and can sink to the ocean's depths. The carbon from the surface is thus transported to the deeper ocean. This uptake of carbon from the atmosphere to the ocean is called the solubility pump.

Marine phytoplankton uses dissolved $\mathrm{CO}_{2}$ during photosynthesis, using nutrients and solar energy, following the simplified equation:

$$
\begin{gathered}
106 \mathrm{CO}_{2}+16 \mathrm{NO}_{3}^{-}+\mathrm{H}_{2} \mathrm{PO}_{4}^{-}+17 \mathrm{H}_{3} \mathrm{O}^{+}+105 \mathrm{H}_{2} \mathrm{O}+\text { solar energy } \\
\rightarrow\left(\mathrm{CH}_{2} \mathrm{O}\right)_{106}\left(\mathrm{NH}_{3}\right)_{16}\left(\mathrm{H}_{3} \mathrm{PO}_{4}\right)+138 \mathrm{O}_{2}
\end{gathered}
$$

The ratios $\mathrm{C}: \mathrm{N}: \mathrm{P}: \mathrm{O}_{2}$ are the Redfield ratios, and the inorganic carbon assimilated by biology constitutes the gross primary production. The difference between gross primary production and the carbon respired by phytoplankton is the net primary production. The phytoplankton that has synthetized organic carbon is then grazed by zooplankton. The depth to which sufficient light penetrates to sustain life is called the euphotic zone and extends to around 100-200 m deep. When plankton dies, it is partially remineralized at the surface, and the remainder sinks to the deeper ocean where it will be progressively remineralized. Carbon can then be found in two forms: particulate organic carbon or dissolved organic carbon. During remineralisation, carbon and nutrients are returned to the solution in dissolved form and can be used again in the euphotic zone for photosynthesis when it is brought back to the surface. Hence, biology also transfers carbon from the surface to the deep ocean leading to carbon being taken up from the atmosphere by the ocean: this is the biological pump. The flux of carbon between dissolved inorganic carbon and marine biology is around $50 \mathrm{GtC} /$ year.

Marine biology not only produces organic carbon, but some organisms also create a shell made of calcium carbonate $\left(\mathrm{CaCO}_{3}\right)$. Most shells are made of calcite (coccolithophores and foraminifera) or aragonite (pteropods), two forms of calcium carbonate. The equation for calcium carbonate production is: 


$$
\mathrm{Ca}^{2+}+\mathrm{CO}_{3}^{2-} \rightarrow \mathrm{CaCO}_{3}
$$

In deep areas in the ocean where water is undersaturated with respect to calcium carbonate, the inverse equation takes place and the shells are progressively dissolved. If they reach the bottom of the ocean, they are buried in sediments. At the ocean surface, the production of calcium carbonate shells leads to a decrease in $\mathrm{CO}_{3}^{2-}$, which increases $\mathrm{CO}_{2}$ due to the following equation:

$$
\mathrm{CO}_{2}+\mathrm{CO}_{3}^{2-}+\mathrm{H}_{2} \mathrm{O} \rightleftarrows 2 \mathrm{HCO}_{3}^{-}
$$

Hence this process, called the carbonate pump, counteracts the two carbon pumps described above.

Finally, ocean circulation impacts on the carbon cycle in the ocean by modifying the distribution of carbon and nutrients, the latter modifying primary production and thus the carbon distribution. Primary production is limited by several nutrients such as nitrate $(\mathrm{N})$, phosphorus $(\mathrm{P})$ and iron $(\mathrm{Fe})$. The concentration of these nutrients mainly depends on transport from the nutrientrich deeper ocean layers to the surface which is nutrient-depleted due to nutrient absorption by marine biology. Hence, in upwelling zones where lots of nutrients are brought to the surface primary production is high. When deep convection is active, it also provides important nutrient transport to the surface favouring production. In the opposite, in low latitude gyres nutrients are lacking and primary production is low. Some regions in the North Pacific and in the Southern Ocean display low productivity despite high nitrate concentrations (HNLC regions for high nitrate low chlorophyll). This is due to the lack of iron which limits production.

\subsubsection{Methane $\left(\mathrm{CH}_{4}\right)$}

Methane is the second most important greenhouse gas after $\mathrm{CO}_{2}$. Discovered in 1976 by Wang et al., its capacity to absorb infrared radiation is around 28 times more efficient than $\mathrm{CO}_{2}$, over a time period of 100 years. Hence, although the concentration of $\mathrm{CH}_{4}$ is 20 times lower than $\mathrm{CO}_{2}$, it still plays a crucial role as a greenhouse gas, with a radiative forcing of around one third that of $\mathrm{CO}_{2}$. The natural sinks and sources of $\mathrm{CH}_{4}$ are different from those of $\mathrm{CO}_{2}$, yielding a distinctly different - although often with some common features - evolution over time as described in section 1.2.3.

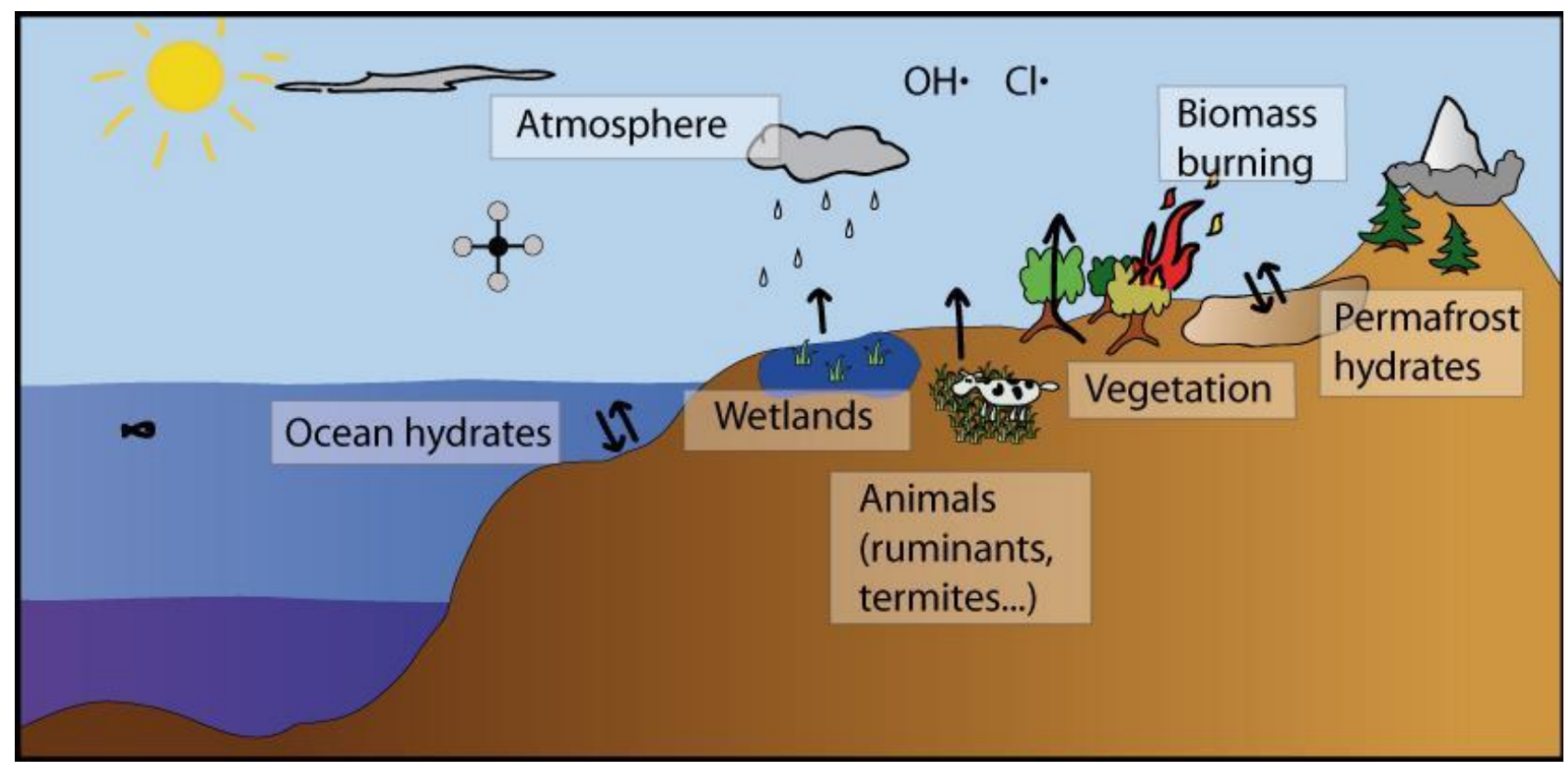


Figure 3. Diagram of the methane cycle.

In the atmosphere, $\mathrm{CH}_{4}$, like $\mathrm{CO}_{2}$, is well mixed over a year. However, while $\mathrm{CO}_{2}$ stays around 100 years in the atmosphere, $\mathrm{CH}_{4}$ has a shorter lifetime of around 9 years. This is because the main sink of $\mathrm{CH}_{4}$ is in the atmosphere: $\mathrm{CH}_{4}$ is oxidized by the hydroxyl radical, $\mathrm{OH}$. Oxidation by $\mathrm{OH}$, which is photochemically produced in the atmosphere, takes place mainly in the troposphere, but also, to a lesser extent, in the stratosphere, and depends on several parameters. First, it depends on the speed of the reaction with $\mathrm{OH}$, hence on temperature. Second, it depends on the quantity of free $\mathrm{OH}$, which itself, depends on other compounds reacting with $\mathrm{OH}$ such as volatile organic compounds (VOCs) and ozone. In addition, the reaction of $\mathrm{CH}_{4}$ with $\mathrm{OH}$ produces the $\mathrm{CH}_{4}$ feedback effect: if $\mathrm{CH}_{4}$ decreases, $\mathrm{OH}$ increases, which in turn reduces even more the concentration of $\mathrm{CH}_{4}$ (Prather, 2007). Another smaller sink of $\mathrm{CH}_{4}$ in the atmosphere is the reaction of $\mathrm{CH}_{4}$ with chlorine gas.

Contrary to $\mathrm{CO}_{2}$, the main natural sources of $\mathrm{CH}_{4}$ are from the continents (Figure 3). The main contributors are wetlands, areas saturated with water such as marshes and swamps. $\mathrm{CH}_{4}$ is produced by microbes (methanogenic archaea) in anoxic conditions in wetlands. Locally, $\mathrm{CH}_{4}$ production strongly depends on oxygen availability, temperature and the composition of the soil. Currently, around three quarters of $\mathrm{CH}_{4}$ production takes place in tropical regions and a quarter in boreal regions. Animals also produce $\mathrm{CH}_{4}$, in particular termites and ruminant animals. In addition, vegetation is also involved in $\mathrm{CH}_{4}$ emission. Vegetation as a $\mathrm{CH}_{4}$ producer is still debated, but it can impact on the transport of $\mathrm{CH}_{4}$ from the soil to the atmosphere. Permafrost can also be a source of $\mathrm{CH}_{4}$ but related uncertainties are high. Finally, $\mathrm{CH}_{4}$ is also emitted by biomass burning. There is also a small continental sink of atmospheric $\mathrm{CH}_{4}$ : the oxidation by methanotrophic bacteria in soils.

A smaller $\mathrm{CH}_{4}$ source is from the ocean, with $\mathrm{CH}_{4}$ coming mainly from coastal regions. However, the ocean could contain large $\mathrm{CH}_{4}$ quantities trapped as methane clathrate in sediments, mainly on continental shelves. Methane clathrate, or methane hydrate, is a compound in which methane is trapped in a crystal of water. Clathrates are stable at low temperature and high pressure. The size of this reservoir is poorly constrained and could contain 500-2500 GtC, a smaller amount than the very high quantities suggested in the 1970's (Milkov, 2004).

While the atmospheric $\mathrm{CH}_{4}$ mixing ratio impacts on climate by modifying the atmospheric radiative balance, climate impacts on the sources and sinks of methane. In particular, wetlands are very dependent on the hydrological cycle and microbial activity, and thus the emission of methane, is strongly dependent on temperature. In addition, in the atmosphere, methane oxidation by $\mathrm{OH}$ radicals is one of the most temperature-sensitive reactions.

\subsubsection{Glacial-interglacial cycles}

The main archives used to infer past changes in the carbon cycle are ice cores and marine sediment cores (see volume 1). While ice cores provide an invaluable direct way of assessing past changes in atmospheric $\mathrm{CO}_{2}$ and $\mathrm{CH}_{4}$, there is no direct record of past ocean and land carbon storage. Fortunately, the carbon element has three isotopes: ${ }^{12} \mathrm{C},{ }^{13} \mathrm{C}$ and ${ }^{14} \mathrm{C}$, and their ratios, which can be measured from foraminifera shells in the sediments, as well as in the air in ice cores, provide clues to understand changes in past carbon reservoirs.

\section{$\underline{\text { Ice cores }}$}

Ice cores recording glacial-interglacial changes are extracted from the Greenland ice sheet in the Northern Hemisphere, and the Antarctic ice sheet in the Southern Hemisphere (Volume 1 chapter 9). The oldest ice obtained from Greenland is $~ 130,000$ years old (NEEM community 
members, 2013), much younger than the oldest ice from Antarctica which is $~ 800,000$ years old (EPICA community members, 2004). This age could be extended further and future expeditions are planned to find and drill Antarctic ice older than a million years (Dahl-Jensen, 2018).

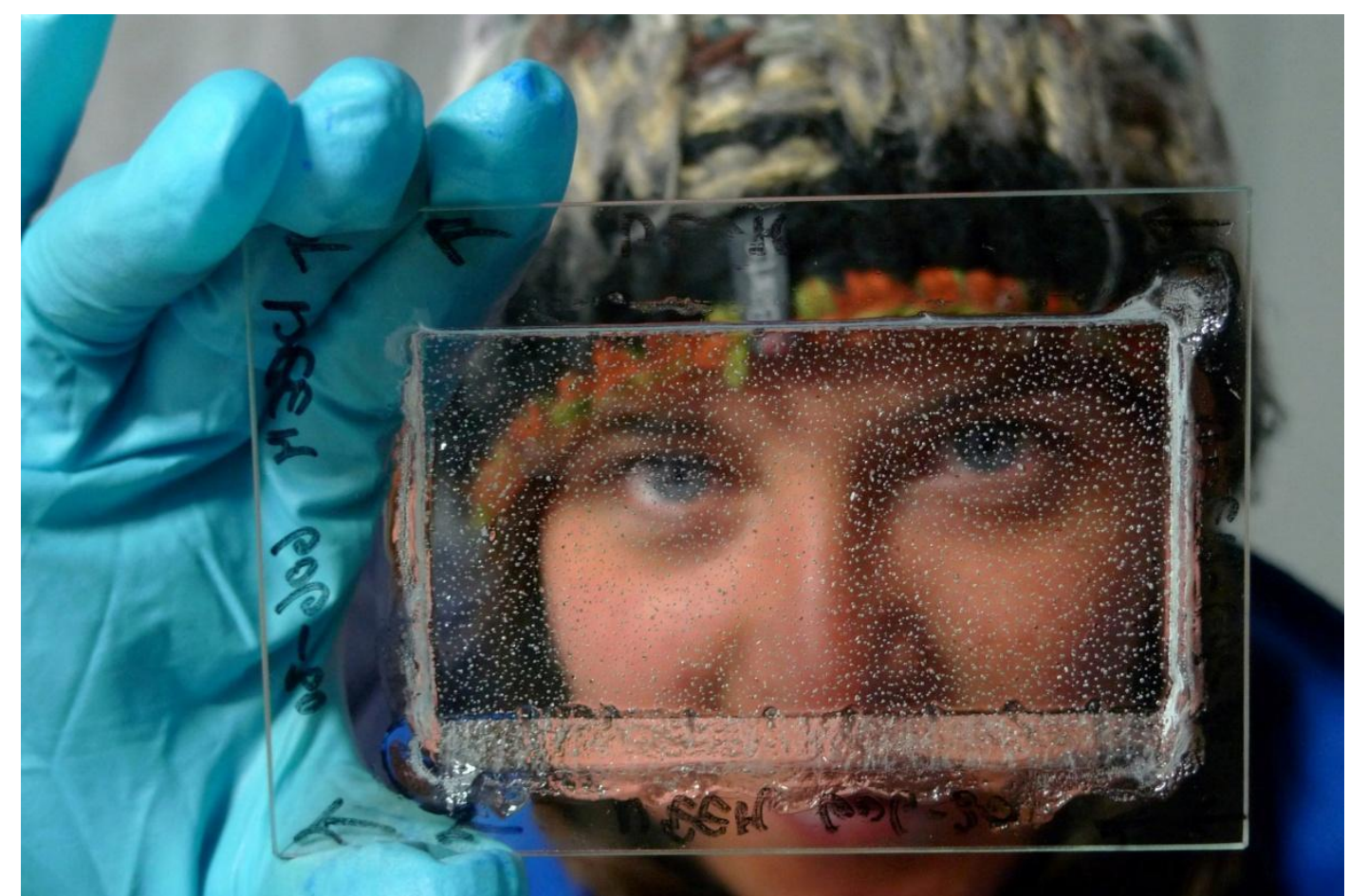

Figure 4. Air bubbles trapped in ice taken from an ice core. Credit: Sepp Kipfstuhl (Alfred Wegener Institute).

Ice cores provide a direct record of past atmospheric gas concentrations, such as $\mathrm{CO}_{2}$ and $\mathrm{CH}_{4}$, thanks to air bubbles trapped in ice (Figure 4). The air is trapped only at the bottom of the firn, a 60$120 \mathrm{~m}$ permeable layer below the surface where snow progressively densifies into ice (see volume 1 chapter 9). It results in an age difference between the ice and the trapped air at a given depth level. This age difference that may be as much as several hundred years and even up to several thousands of years in the case of central Antarctic sites (Schwander and Stauffer, 1984). Estimates of the age difference between the ice and the entrapped air are possible but there are associated uncertainties which are detailed in Volume 1 chapter 8. The first reliable measurements of past $\mathrm{CO}_{2}$ changes recorded in Antarctic ice were published in the 1980s, initially covering the last 30,000 years (Delmas et al., 1980), then the last 160,000 years (Barnola et al., 1987), and now as much as the last 800,000 years (Lüthi et al., 2008; Bereiter et al., 2015, Figure 5). Note that only past atmospheric $\mathrm{CO}_{2}$ concentrations determined from Antarctic ice cores are reliable, as Greenland ice is prone to in situ production of $\mathrm{CO}_{2}$, which alters the atmospheric $\mathrm{CO}_{2}$ concentration already within the ice (Tschumi and Stauffer, 2000). Measurements of past $\mathrm{CH}_{4}$ concentrations extracted from both Greenland and Antarctic ice cores are reliable. While the first $\mathrm{CH}_{4}$ records covered the last 160,000 years (Chappellaz et al., 1990), they also now date back to 800,000 years (Loulergue et al., 2008). In addition to greenhouse gas concentrations, measurements of the air from ice cores now also involve $\delta^{13} \mathrm{C}$ from $\mathrm{CO}_{2}$, termed $\delta^{13} \mathrm{CO}_{2}$ (Schneider et al., 2013, Schmitt et al., 2012, Lourantou et al., 2010). Ice cores offer a unique possibility to quantify the sequence of events occurring between greenhouse gas variations and changes in ice core tracers inform on other parts of the climate system such as local surface temperature using ice $\delta^{18} \mathrm{O}$ (see volume 1 chapter 11 ). 


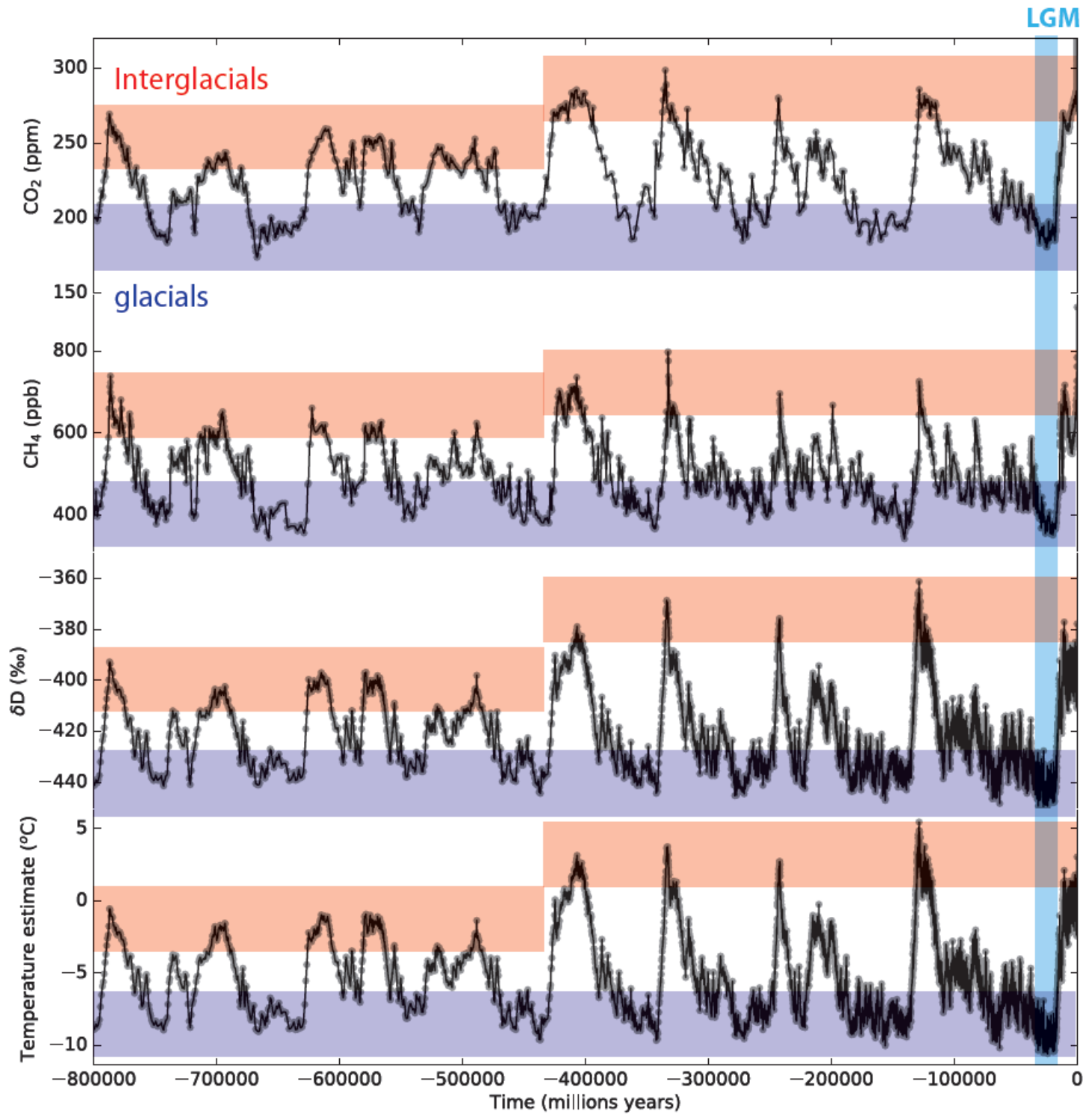

Figure 5. Evolution of $\mathrm{CO}_{2}(\mathrm{ppm}), \mathrm{CH}_{4}(\mathrm{ppb})$, deuterium $(\%)$ and temperature $\left({ }^{\circ} \mathrm{C}\right)$ over the last 800000 years. The Last Glacial Maximum (LGM) is indicated by the blue bar. Data from EPICA community members (2004), Jouzel et al., (2007), Loulergue et al., (2008), Bereiter et al., (2015).

\section{$\underline{\text { Sediment cores }}$}

At the bottom of oceans and lakes, sediments progressively accumulate as various particles and debris are deposited. They include both organic material, such as shells, and inorganic material, such as clay. The invention of the first piston corer in 1947 by Kullenberg allowed marine sediment cores to be extracted from the ocean bottom, yielding a wealth of information on past ocean changes (volume 2 chapter 21). In particular, sediments provide information on past marine productivity, for example by measuring the fraction of organic material, calcite or opal (biogenic silica). The proportion of organic material measured in upwelling zones is large, because productivity is high. In regions where organic material is not well preserved, silicate can be used as another proxy for biological productivity. Other proxies are also used, such as ${ }^{10} \mathrm{Be}$, authigenic $\mathrm{U}$, $\left.{ }^{231} \mathrm{~Pa} /{ }^{230} \mathrm{Th}\right)$. They rely on the fact that some elements preferentially fix to particles $(\mathrm{Th})$ while others remain in solution $(\mathrm{U}, \mathrm{Pa})$. Their ratio gives an indication of past particle flux in the water column, hence biological productivity. 
As detailed in volume 1 chapter 21, carbon isotopes are measured in foraminifera shells providing constraints on the carbon cycle. Whenever carbon is exchanged at an interface, fractionation takes place, which modifies $\delta^{13} \mathrm{C}$ defined as:

$$
\delta^{13} C=\left(\frac{\left(\frac{{ }^{13} C}{{ }^{12} C}\right)_{\text {sample }}}{\left(\frac{{ }^{13} C}{{ }^{12} C}\right)_{\text {standard }}}-1\right) \times 1000
$$

The standard is the PDB (Peedee belemnite) carbon isotope standard, which corresponds approximately to average limestone [Craig, 1957].

For example, biological activity preferentially uses the light ${ }^{12} \mathrm{C}$ over ${ }^{13} \mathrm{C}$, so that plants or plankton are enriched in ${ }^{12} \mathrm{C}$, and the environment (atmosphere for terrestrial biosphere, surface ocean for plankton) has higher $\delta^{13} \mathrm{C}$ values (Figure 6). A more active biological productivity will thus increase the $\delta^{13} \mathrm{C}$ in the surrounding environment.

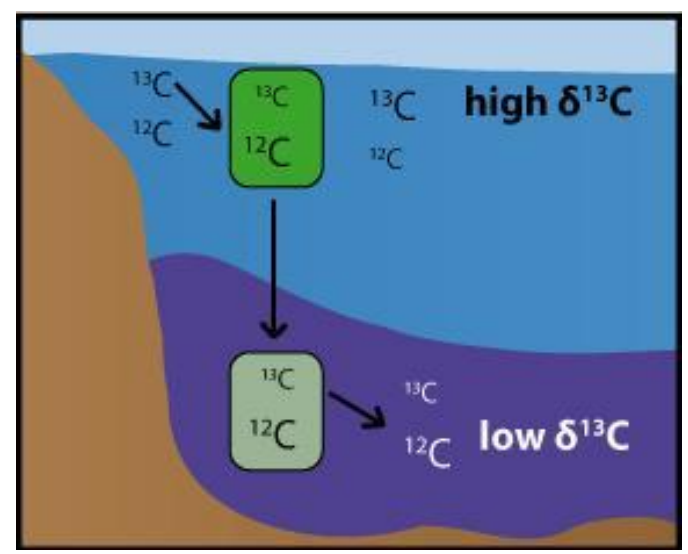

Figure 6. Diagram of $\delta^{13} \mathrm{C}$ in the surface and deep ocean. In the surface waters, the value of oceanic $\delta^{13} \mathrm{C}$ is high because of photosynthetic activity, which preferentially uses light ${ }^{12} \mathrm{C}$, thus enriching the environment with heavy ${ }^{13} \mathrm{C}$. In the deep ocean, remineralisation releases carbon with more ${ }^{12} \mathrm{C}$, therefore lowering $\delta^{13} \mathrm{C}$.

Sediments on continents can also be extracted and studied, but continental sediment cores are scarcer than their marine counterpart. Pollen in these sediments, for example in loess, give information on past local plant types and help to reconstruct past vegetation changes.

\section{Past changes}

Ice core data show large changes in concentrations of $\mathrm{CO}_{2}$ and $\mathrm{CH}_{4}$ between warm interglacials and cold glacials (Figure 5). Concentrations of both $\mathrm{CO}_{2}$ and $\mathrm{CH}_{4}$ are higher during interglacials: around $280 \mathrm{ppm}$ for $\mathrm{CO}_{2}$ and $780 \mathrm{ppbv}$ for $\mathrm{CH}_{4}$, and lower during glacials: around 190 ppm for $\mathrm{CO}_{2}$ and 320 ppbv for $\mathrm{CH}_{4}$ (Lüthi et al., 2008; Bereiter et al., 2015; Loulergue et al., 2008). While values are relatively similar during all glacials, the interglacial $\mathrm{CO}_{2}$ values are around 20 ppm lower for the older interglacials (before 430ka) compared to the more recent ones. The concomitant records of climate and air composition demonstrate the strong link between climate and greenhouse gases, both for $\mathrm{CO}_{2}$ (Barnola et al., 1987; Petit et al., 1999; Siegenthaler et al., 2005; Lüthi et al., 2008) and $\mathrm{CH}_{4}$ (Chappellaz et al., 1990; Petit et al., 1999, Spahni et al., 2005; Loulergue et al., 2008). Recent research has shown that $\mathrm{CO}_{2}$ and Antarctic temperature changed synchronously at the start of the two last deglaciations (within 200 years; Parrenin et al., 2013; Landais et al., 2013). 
Several explanations have been put forward to explain the atmospheric $\mathrm{CO}_{2}$ waxing and waning during glacial-interglacial cycles. Atmospheric $\mathrm{CO}_{2}$ changes are driven by changes in carbon storage in other reservoirs, particularly on land and in the ocean.

On land, the lower sea level, by $120 \mathrm{~m}$, during glacial time increased the surface area where plants could develop, although the larger ice sheets covering part of North America and Eurasia reduced the available area. Overall, due to the colder and drier climate, as well as reduced atmospheric $\mathrm{CO}_{2}$ concentration, photosynthesis by land vegetation is reduced and the terrestrial biosphere tends to represent a smaller carbon reservoir during glacial period, which would increase atmospheric $\mathrm{CO}_{2}$, not lower it. This is indicated by ocean $\delta^{13} \mathrm{C}$ which decreased by around $0.03-$ $0.04 \%$ during the Last Glacial Maximum compared to the pre-industrial level. This is explained by the transfer of continental carbon with low $\delta^{13} \mathrm{C}$ values (due to fractionation during photosynthesis) to the ocean (Shackleton, 1977; Bird et al., 1994), causing a reduction in continental carbon of around 270-720 GtC. An understanding of the changes in the terrestrial biosphere can also be obtained from paleo-biomes, using pollen from sediment cores (Adams et al., 1990; Crowley, 1995; Maslin et al., 1995) which show a carbon loss of around 750-1350 GtC. Pollen data have also been used to reconstruct maps of vegetation types during the LGM (Figure 7). 

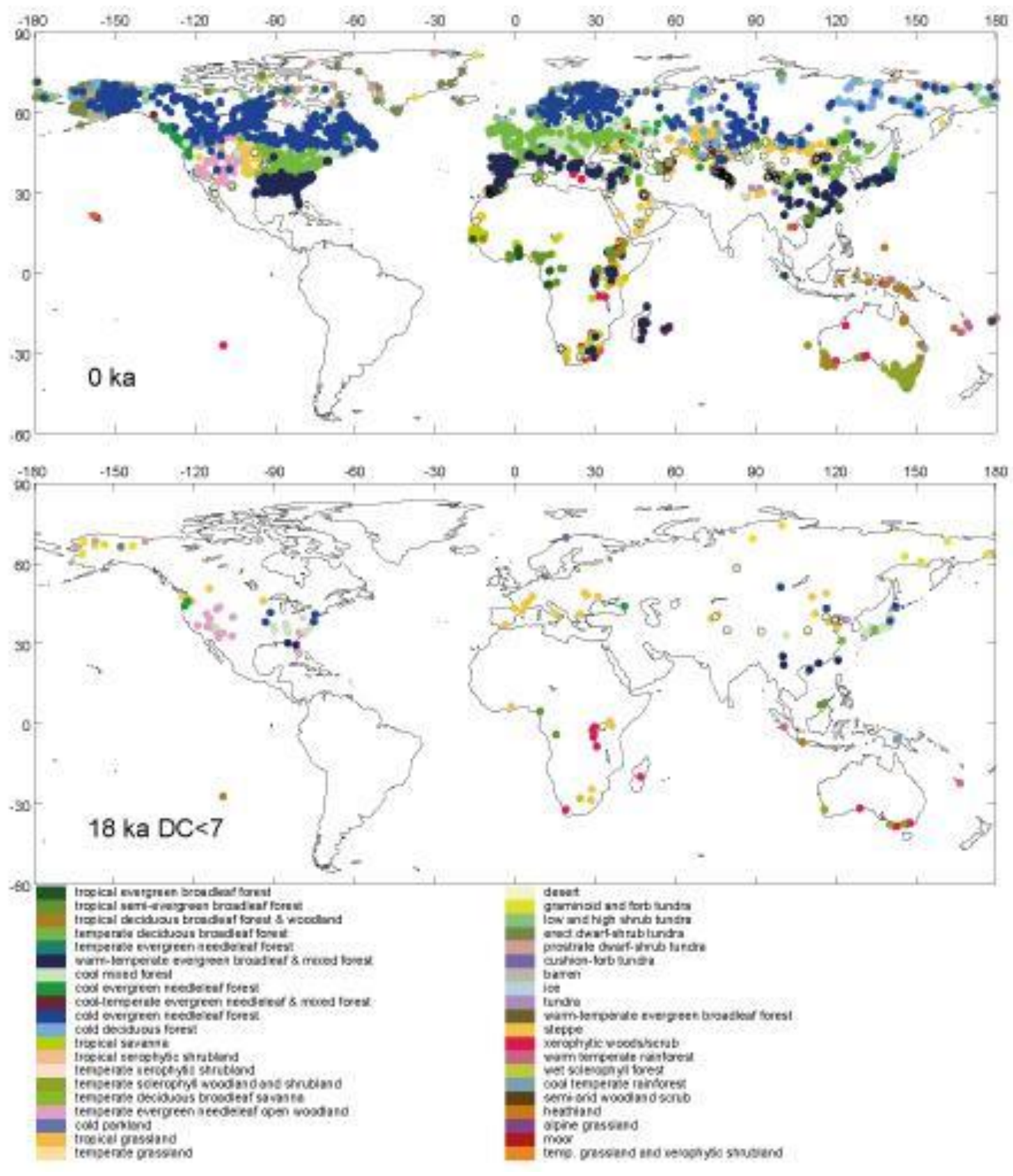

Figure 7. Land vegetation maps for the modern era and the LGM, data from Prentice et al. (2000), Harrison et al. (2001), Bigelow et al. (2003) and Pickett et al. (2004). This figure with homogenised nomenclature has been downloaded from http://www.bridge.bris.ac.uk/resources/Databases/BIOMES_data.

However, frozen soils, i.e. permafrost, may have increased in glacial times, potentially storing more carbon, which could partly explain the lower $\mathrm{CO}_{2}$ (Ciais et al., 2012) and help resolve the $\delta^{13} \mathrm{CO}_{2}$ signal recorded in ice cores, which strongly depends on land carbon changes (Crichton et al., 2016).

Although permafrost probably played a role, most of the change is likely to have come from the ocean, which is a much bigger carbon reservoir. In addition, $\delta^{13} \mathrm{C}$ measurements from sediment cores indicate large changes in the ocean (Curry and Oppo, 2005; Marchal and Curry, 2008; Hesse et al., 2011). In the ocean, the carbon cycle changes could originate from modifications of biological activity and physical or chemical changes. Known processes include temperature change as colder temperatures lead to more carbon being stored in the ocean. The sea level drop of $\sim 120 \mathrm{~m}$ during glacial maxima results in higher concentrations of salinity, which causes a reduction in the 
storage capacity of carbon in the ocean, and an increase in nutrients, which increases biological activity and thus increases ocean carbon storage. However, these processes are not sufficient to fully explain the decrease in $\mathrm{CO}_{2}$ decrease (see review by Sigman and Boyle, 2000; Archer et al., 2000), and additional mechanisms are needed.

Four main hypotheses have been proposed to explain the $\mathrm{CO}_{2}$ lowering by increased ocean carbon storage: increased biological pump, isolation of the ocean from the atmosphere due to sea ice coverage, changes in ocean dynamics, and carbonate compensation.

The biological pump causes more carbon to be stored when it is stimulated, for example when more nutrients are delivered to the ocean (Broeker and Peng, 1982). In regions of high nutrients low chlorophyll (HNLC), biological activity is limited due to the lack of iron. An influx of iron to these zones during glacial periods would increase biological activity. Alternatively, the biological pump could also store more carbon if it becomes more efficient, for example with a greater carbon to nutrient ratio (Broecker and Peng, 1982) or a switch of plankton species with higher productivity (Archer and Meier Reimer, 1994). However, both data and model simulations have shown that changes in biological activity are not sufficient to sufficiently account for the decrease in atmospheric $\mathrm{CO}_{2}$ (Kohfeld et al., 2005; Bopp et al., 2003a; Tagliabue et al., 2009; Lambert et al., 2015).

Increased sea ice coverage has also been proposed, as this could isolate the ocean, preventing carbon from getting to the atmosphere, hence lowering atmospheric $\mathrm{CO}_{2}$ (Stephens and Keeling, 2000). But such an impact has only been simulated in very simple models, more complex models do not show such an effect on $\mathrm{CO}_{2}$ (Archer et al., 2003).

Most current theories involve changes in ocean dynamics, and point to the Southern Ocean (Fischer et al., 2010). A larger ocean volume occupied by AABW, or slower overturning, could result in more carbon stored in the deep ocean, reducing atmospheric $\mathrm{CO}_{2}$. Ocean circulation changes are supported by data generally indicating a reduced NADW and a more stratified Southern Ocean (Adkins, 2013). In particular, $\delta^{13} \mathrm{C}$ measurements show lower $\delta^{13} \mathrm{C}$ values in the deep glacial ocean, especially around Antarctica, and higher values near the surface (Curry and Oppo, 2005; Marchal and Curry, 2008; Hesse et al., 2011). In addition, very salty water has been measured in the deep Southern Ocean (Adkins et al., 2002). Complementary data, such as from neodymium isotopes (Basak et al., 2018), B/Ca ratio (Yu et al., 2016) and $\Delta^{14} \mathrm{C}$ (Skinner et al., 2010), also point towards changes in the circulation in the Southern Ocean.

Comparison of model simulations over the last decade have shown that models simulate a large range of ocean circulation changes, which are generally opposite to those deduced from data. In PMIP3, most models simulate a strengthening and deepening of the NADW with LGM boundary conditions (Muglia and Schmittner, 2015). Yet simulations have shown that better agreement with $\delta^{13} \mathrm{C}$ and $\mathrm{CO}_{2}$ data requires lower NADW intensity and/or shoaling of NADW (Tagliabue et al., 2009; Tschumi et al., 2011; Menviel et al., 2017). This is also seen in terms of water mass volume with a smaller volume of NADW and a larger volume of AABW filling the ocean. The latter has a larger DIC content, resulting in more carbon in the ocean when the AABW occupies relatively more volume than the NADW (Brovkin et al., 2012). This is referred to as the "standing volume effect" (Skinner, 2009).

Changes of ocean circulation could be due to changes of winds (Anderson et al., 2009, Toggweiler et al., 2006). But data show no clear evidence of large wind changes (Kohfeld et al., 2013) and model simulations have shown that this is unlikely to have had a strong effect on the carbon cycle (Menviel et al., 2008a). It could also be linked to ocean diffusion (Bouttes et al., 2009; 2011) and particularly to bottom topography induced diffusion (De Boer et al., 2014). Alternatively, 
it could be linked to sea ice changes and modifications in bottom water formation (Ferrari et al., 2014; Bouttes et al., 2010). Indeed, sea ice formation around Antarctica was probably enhanced, especially during winter (Gersonde et al., 2005). Yet models usually fail to represent glacial sea ice extent (Roche et al., 2012; Goosse et al., 2013; Marzocchi et al., 2017). Improving sea ice formation in models during the LGM and the sinking of dense water around Antarctica should help towards explaining the glacial atmospheric $\mathrm{CO}_{2}$ concentration.

Finally, on longer timescales of a few thousand years, carbonate compensation amplifies the increase of oceanic carbon storage, by maintaining a balance between inputs and outputs of alkalinity fluxes (Figure 8). For example, (1) if $\left[\mathrm{CO}_{2(\mathrm{aq})}\right]$ increases (for example due to the solubility pump), the equation below is displaced towards more $\left[\mathrm{HCO}_{3}^{-}\right]$, reducing $\left[\mathrm{CO}_{3}{ }^{2-}\right]$.

$$
\mathrm{CO}_{2}+\mathrm{CO}_{3}^{2-}+\mathrm{H}_{2} \mathrm{O} \rightleftarrows 2 \mathrm{HCO}_{3}^{-}
$$

(2) When $\left[\mathrm{CO}_{3}{ }^{2-}\right]$ is reduced, the saturation horizon, the limit between oversaturated and undersaturated water, is shifted upwards and a larger volume of water is undersaturated. (3) The larger undersaturated zone results in more $\mathrm{CaCO}_{3}$ dissolution, which increases $\left[\mathrm{CO}_{3}{ }^{2-}\right.$, counteracting the initial reduction and leading to a lowering of $\left[\mathrm{CO}_{2}\right]$ as the previous equation is shifted to the right, allowing the ocean to take up more $\mathrm{CO}_{2}$ from the atmosphere. (4) When $\left[\mathrm{CO}_{3}{ }^{2-}\right]$ is increased, the oversaturated zone increases and the saturation horizon is shifted down until a new equilibrium is reached. Overall, the ocean takes up more carbon with this mechanism through dissolution of $\mathrm{CaCO}_{3}$.

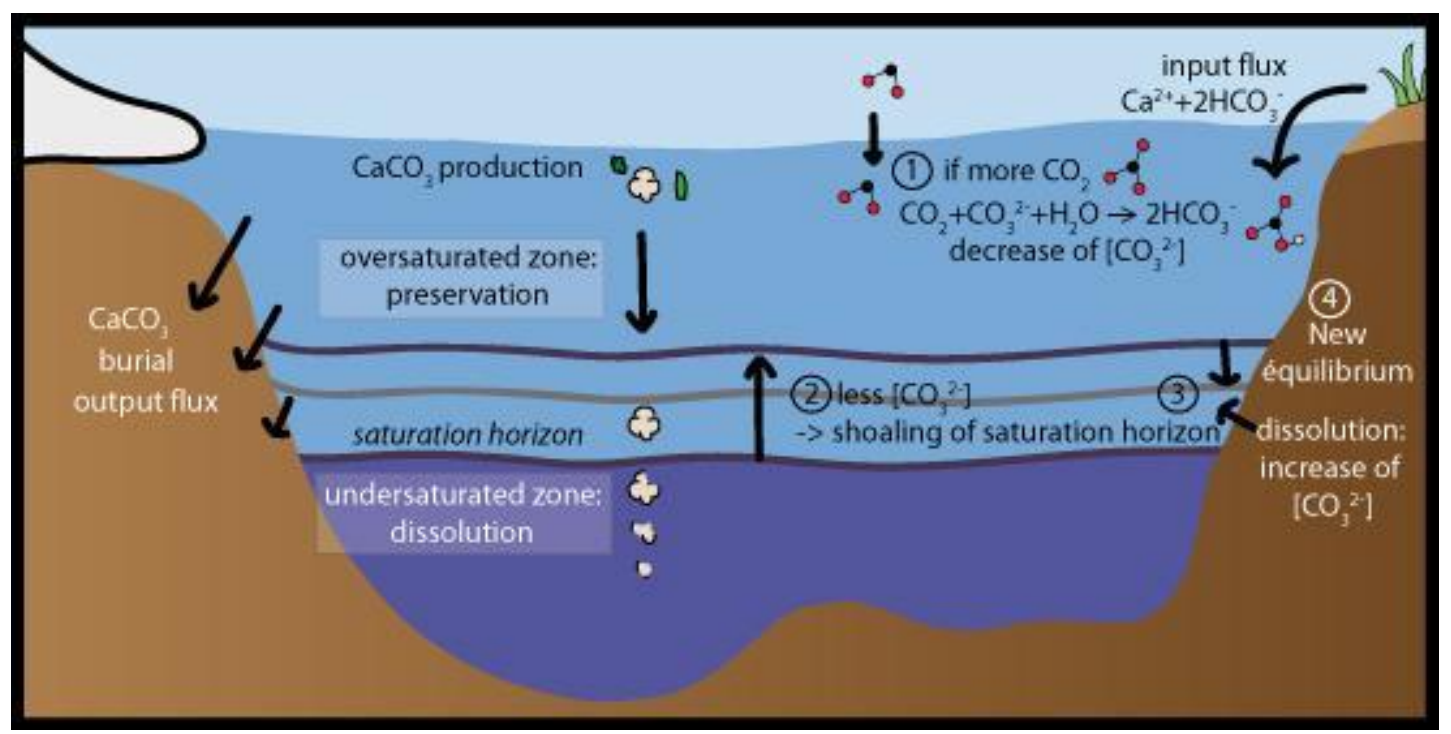

Figure 8. Diagram of the carbonate compensation mechanism.

The concomitant lowering of $\mathrm{CH}_{4}$ during the glacial period could be due to either a decrease in $\mathrm{CH}_{4}$ sources, mainly wetlands, or an increase in sinks, mainly more oxidation by increased $\mathrm{OH}$.

During the LGM, the colder climate, larger ice sheets and reduced hydrological cycle all led to a reduction of wetlands and reduced emissions. The first hypothesis to explain the lower $\mathrm{CH}_{4}$ concentration during the LGM has thus focused on reduced emissions, possibly from low latitude wetlands (Chappellaz et al., 1993). Later, process-based models were developed and used to evaluate emissions (Valdes et al., 2005; Kaplan et al., 2006, Weber et al., 2010). But the resulting reduction of emissions was not enough to account for the low $\mathrm{CH}_{4}$ concentration detected in ice cores. It was then hypothesized that the oxidizing atmospheric capacity had changed, for instance through a reduction of emissions of volatile organic compounds (VOCs) from forests (Valdes et al., 2005). The VOCs react with $\mathrm{OH}$ in the same way as $\mathrm{CH}_{4}$, thus constituting an $\mathrm{OH}$ sink, which increases the lifetime of $\mathrm{CH}_{4}$. If more VOCs are produced, $\mathrm{OH}$ concentration is reduced and the concentration of $\mathrm{CH}_{4}$ is increased. However, more complex chemical models show that certain 
processes compensate for the reduced atmospheric oxidizing capacity, such as temperature, humidity, lightening (Levine et al., 2011; Murray et al., 2014). In conclusion, it now appears that the atmospheric oxidizing capacity is probably of secondary importance, as process-based models and the methane retroaction (less $\mathrm{CH}_{4}$ leads to more $\mathrm{OH}$, hence less $\mathrm{CH}_{4}$ ) estimate emissions that explain almost entirely the low $\mathrm{CH}_{4}$ value at LGM (Quiquet et al., 2015).

Beyond the problem of the large changes in glacial-interglacial GHG concentrations, another issue was raised in the 2000's when data became available for periods older than 430000 years BP. As shown on figure 5, older interglacials before $430000 \mathrm{ka} \mathrm{BP}$ (before the "Mid Brunhes Event") are characterized by a colder climate than more recent interglacials, associated to lower GHG concentrations. The colder interglacial climate can be attributed to different orbital configurations and lower $\mathrm{CO}_{2}$ (Yin and Berger, 2010, 2012) but the reason for the lower GHG concentrations still remains to be explained (Bouttes et al., 2018).

\subsubsection{Abrupt changes}

At the centennial to millennial scale, climate variability is superimposed onto the orbitalscale glacial-interglacial cycles and is recorded by specific expressions at different latitudes and in different climate archives (Clement and Peterson, 2008; see volume 2 chapter 8). Indeed, Greenland ice cores unveiled a succession of events called Dansgaard-Oeschger (D-O) events during the last glacial period (Dansgaard et al., 1993; North Greenland Ice Core Project members, 2004). Typically, a DO event is depicted as an abrupt warming of $5-16^{\circ} \mathrm{C}$ of the mean annual surface temperature within a few decades toward a relatively mild phase. This phase is then usually characterised by a gradual cooling over several centuries and its end is marked by a rapid cooling leading to a relatively stable cold phase persisting over several centuries or even up to a thousand years. The signature of DO events is recorded in continental and marine records in the Northern Hemisphere. In the Southern Hemisphere, there are counterparts to these DO events. Ice cores indicate more gradual (millennial-scale) warming in Antarctica during the Greenland cold phases (EPICA community members, 2006; Barker et al., 2009; WAIS Divide Project Members, 2015). The antiphase relationship between the two hemispheres is attributed to the thermal bipolar seesaw, a mechanism whereby heat is redistributed in the Atlantic Ocean (Stocker and Johnsen, 2003).

In addition to the succession of Dansgaard-Oeschger events, another prominent feature identified in marine sediments from the North Atlantic is the occurrence of the Heinrich events. Heinrich events are identified by the presence of debris in sediments, and were first discovered by Ruddiman in 1977. These debris are too big to be transported by oceanic currents, and in 1988 Heinrich proposed that they could have been brought by icebergs which melted above the zone where these ice rafted debris (IRD) were found in sediments (Hemming, 2004).

Antarctic ice core records show a rapid rise in atmospheric $\mathrm{CO}_{2}$ of around $15 \mathrm{ppm}$ over 2000 to 4000 years (Figure 9), generally synchronous with the millennial-scale Antarctic warming, followed by a more gradual decrease than the Antarctic temperature drop (Ahn and Brook, 2008; Bereiter et al., 2012). Measurements have shown that the $\mathrm{CO}_{2}$ rise was not steady, but punctuated by events with a rapid increase (Ahn et al., 2012). Other data measurements have resulted in several carbon sources being suggested to explain these increases in atmospheric $\mathrm{CO}_{2}$, such as the Southern Ocean (Gottschalk et al., 2016) or the North Atlantic (Ezat et al., 2017). 


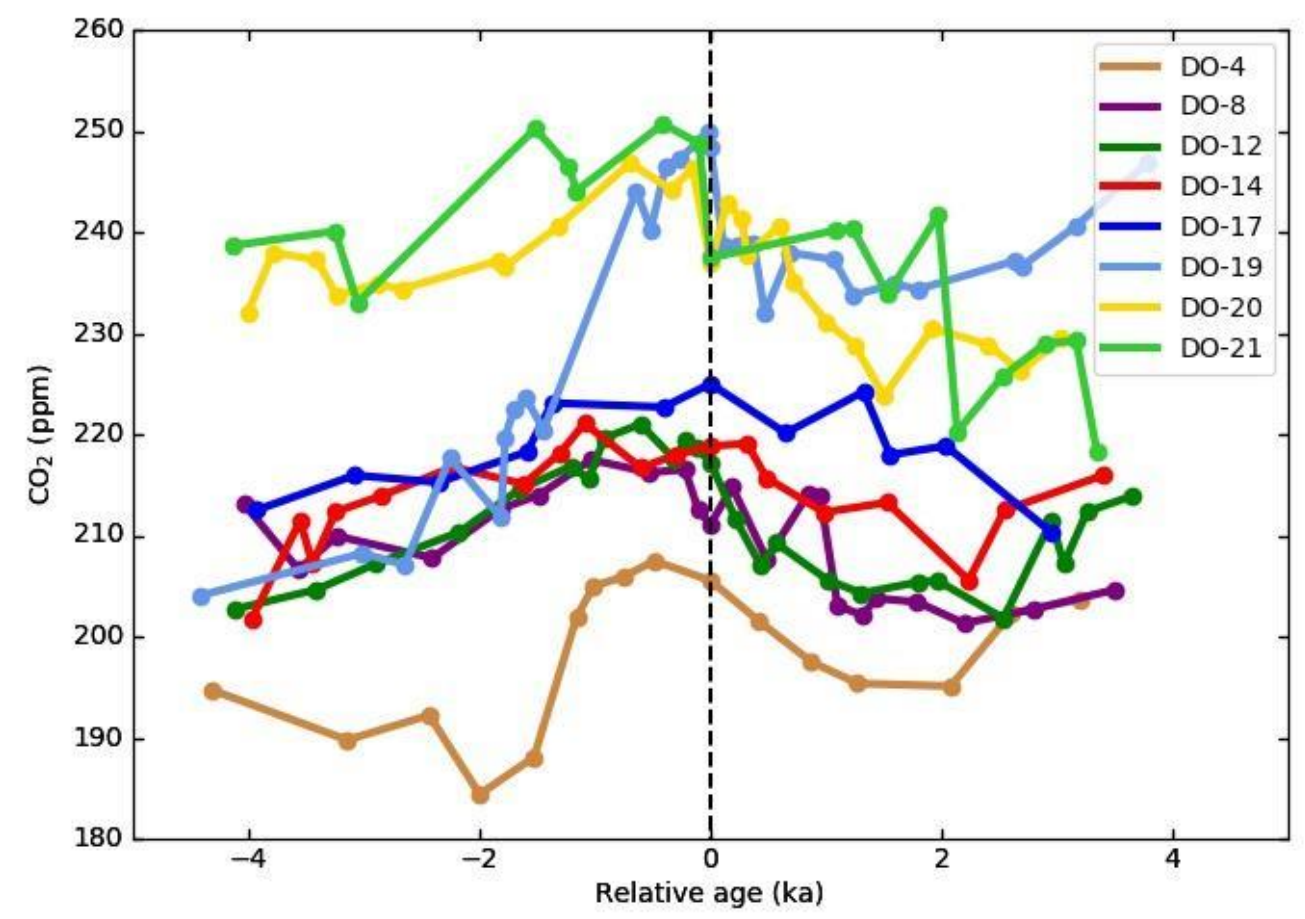

Figure 9. $\mathrm{CO}_{2}$ variations relative to abrupt warming in Greenland as presented in Ahn and Brook (2008).

These rapid changes of atmospheric $\mathrm{CO}_{2}$ have been studied only relatively recently as previously, the temporal resolution in the records was not sufficient. Temperature changes have been studied for longer since more high resolution data were available. To replicate these rapid climate changes in simulations, modellers have found that artificially adding freshwater to the North Atlantic, for example theoretically due to the melting of numerous icebergs, could slow down or even stop the Atlantic meridional overturning circulation. This then generally leads to warming in the North Hemisphere and cooling in the South Hemisphere, in line with changes observed in the data (see volume 2 chapter 8 ).

More recently, the impact of such hosing experiments on the carbon cycle and atmospheric $\mathrm{CO}_{2}$ evolution has also been tested in carbon-climate models, to evaluate the role of the terrestrial biosphere and the ocean, in particular, in coupled ocean-atmosphere-terrestrial biosphere models. The model response to the freshwater input appears to be very dependent on the type, duration and amplitude of the freshwater input, on the background climate (glacial vs pre-industrial) and the model. For example, the LOVECLIM model simulates a 15 ppmv increase in the context of a preindustrial climate, but a $10 \mathrm{ppm} \mathrm{CO}_{2}$ decrease in a glacial climate in response to a decrease in the AMOC driven by the same freshwater input (Menviel et al., 2008b). In both cases, the ocean takes up more carbon and the terrestrial biosphere loses carbon, but the balance between the two outcomes results in opposite effects on the atmospheric $\mathrm{CO}_{2}$. This balance also depends on the different time reactions of the carbon reservoirs: vegetation reacts more rapidly than the ocean.

In general, most models simulate an overall increase in atmospheric $\mathrm{CO}_{2}$ ranging from a few ppm up to more than $20 \mathrm{ppm}$, depending on the model and the size of the freshwater flux (Obata, 2007; Schmittner and Galbraith, 2008; Menviel et al., 2008b; Bozbiyik et al., 2011; Bouttes et al., 2012; Matsumoto and Yokoyama, 2013), but the causes are different: in some models the ocean gains carbon and the terrestrial biosphere loses carbon (Obata, 2007; Menviel et al., 2008b; Bozbiyik et al., 2011) while in others it is the opposite with the ocean losing carbon and terrestrial biosphere gaining carbon (Schmittner and Galbraith 2008; Bouttes et al., 2012; Matsumoto and 
Yokoyama, 2013). Alternatively, simulations with artificially increased salinity in the Southern Ocean have been tested, resulting in a strengthening of the AABW and a loss of ocean carbon, yielding an overall $\mathrm{CO}_{2}$ increase of around $20 \mathrm{ppm}$ (Menviel et al., 2015). In general, simulations with atmosphere-ocean-terrestrial biosphere models in glacial background climate produce a large range of $\mathrm{CO}_{2}$ changes due to the different processes, which are summed up in Figure 10.

\section{Abrupt events in glacial climate}

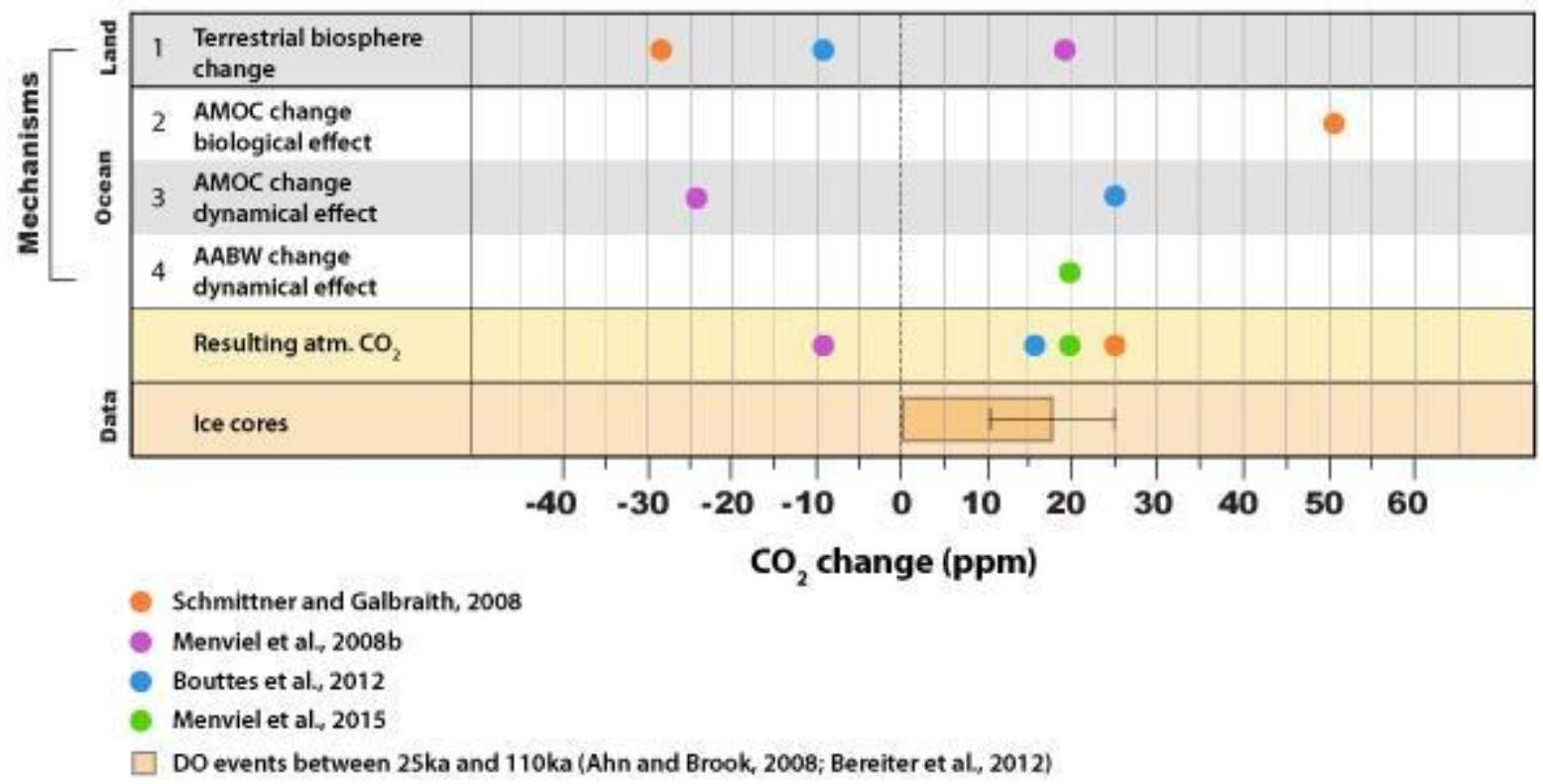

Figure 10. Changes of atmospheric $\mathrm{CO}_{2}$ due to different processes in atmosphere-ocean-terrestrial biosphere model simulations with glacial background climate. Figure modified from Mariotti et al., 2013. Model data are taken from the simulations with maximum $\mathrm{CO}_{2}$ change and at the time when atmospheric $\mathrm{CO}_{2}$ for ocean and land carbon changes is at a peak.

In addition, rapid $\mathrm{CO}_{2}$ changes during the last deglaciation have been recently highlighted, such as the rapid $\mathrm{CO}_{2}$ rise concomitant to the warming in the Northern Hemisphere at the Bølling Allerød around 14,600 years ago (Marcott et al., 2014). On top of changes in the Atlantic meridional overturning circulation, permafrost thawing, releasing large quantities of $\mathrm{CO}_{2}$ trapped in frozen soil, has been suggested as a potential driver of the $\mathrm{CO}_{2}$ rise (Köhler et al., 2014).

Changes in atmospheric methane $\left(\mathrm{CH}_{4}\right)$ concentration measured in ice cores are linked closely to the rapid surface temperature variations in Greenland during the last glacial period. In particular, $\mathrm{CH}_{4}$ increases of 100-200 ppbv are associated with the abrupt DO warming events. $\mathrm{CH}_{4}$ concentration is a global signal that reflects the response of the terrestrial biosphere, mainly wetlands, to hydroclimate changes (Brook et al., 2000) and its close link with Greenland temperature is classically interpreted as reflecting changing $\mathrm{CH}_{4}$ emissions from tropical and boreal wetlands in phase with Greenland temperature (Chappellaz et al., 1993). A detailed study of the abrupt Bølling warming, the penultimate warming in the series of abrupt climate changes during the last glacial, suggests that changes in Greenland temperatures and atmospheric $\mathrm{CH}_{4}$ emissions occurred essentially synchronously (within $20 \mathrm{yr}$; Rosen et al., 2014). $\mathrm{CH}_{4}$ concentrations measured in Greenland ice cores are higher than those measured in Antarctic ice cores primarily because of enhanced $\mathrm{CH}_{4}$ emissions in the Northern Hemisphere due to its larger land area (Chappellaz et al., 1997). However, rapid $\mathrm{CH}_{4}$ changes are seen in both hemispheres and this feature is commonly used to synchronise Antarctic and Greenland ice core chronologies (Blunier et al., 1998; Buizert et al., 2015). 


\subsection{Nitrogen cycle}

\subsubsection{Natural nitrogen cycle}

Nitrogen $(\mathrm{N})$ interacts with climate in two ways. First, like carbon dioxide and methane, nitrous oxide $\mathrm{N}_{2} \mathrm{O}$ is a greenhouse gas. It is in fact more powerful than $\mathrm{CO}_{2}$ or $\mathrm{CH}_{4}$, but its atmospheric concentration is less, currently $325 \mathrm{ppb}$ (NOAA, http://esrl.noaa.gov/gmd/). Second, nitrogen is also a limiting nutrient for the growth of vegetation on land and in the ocean, along with other nutrients such as phosphate. Nitrogen is essential for photosynthesis, which produces organic carbon. This connects the nitrogen cycle to the carbon cycle and atmospheric $\mathrm{CO}_{2}$ concentration, and ultimately connects the nitrogen cycle to climate.

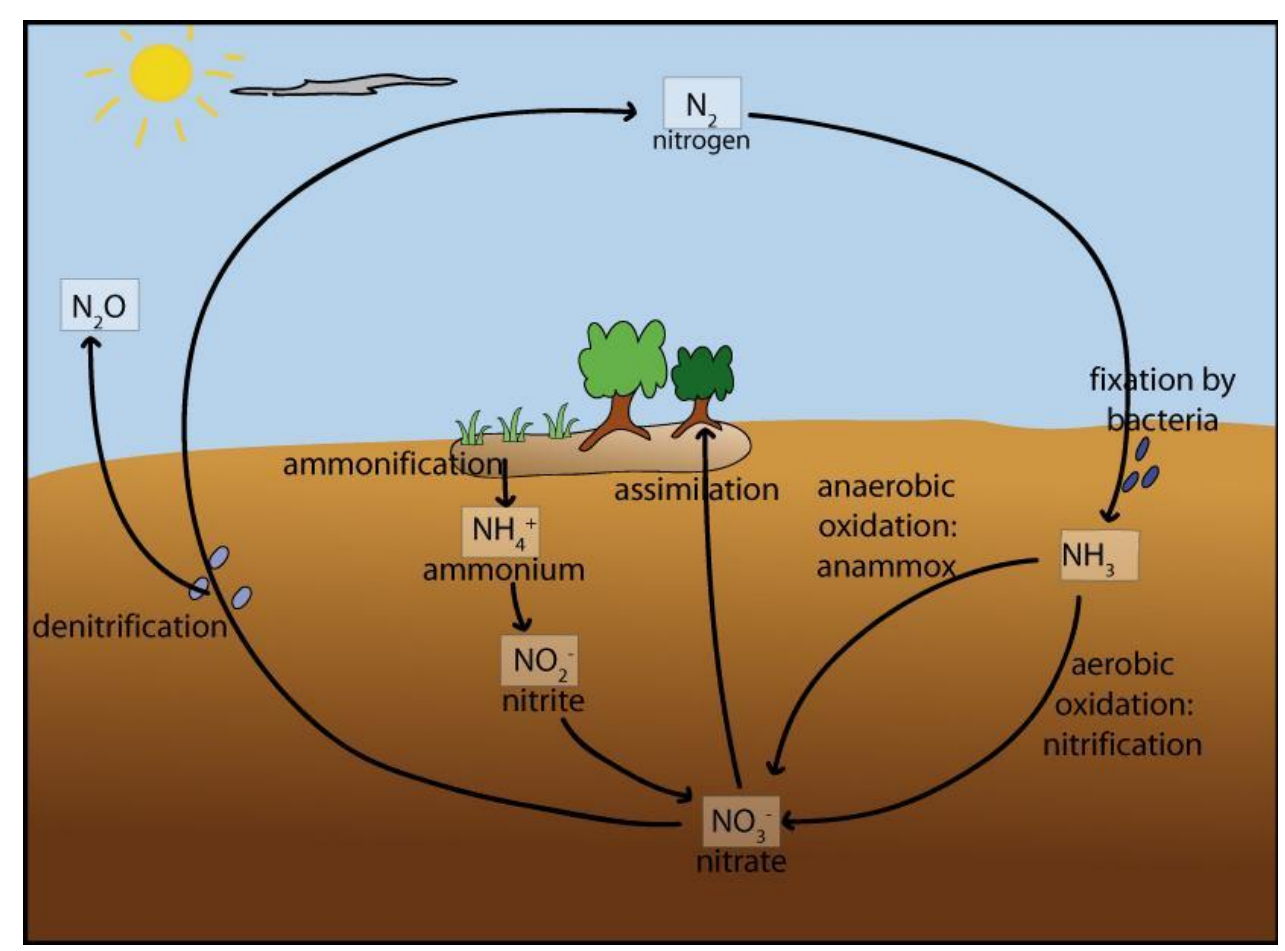

Figure 11. Diagram of the nitrogen cycle

The nitrogen cycle is governed by biochemical reactions oxidising and reducing nitrogen which can be divided into three main processes: $\mathrm{N}_{2}$-fixation, nitrification and denitrification (Figure 11). These processes take place both in the ocean and on land.

Although $\mathrm{N}_{2}$ is very abundant in the atmosphere it cannot be used in this form by most organisms. $\mathrm{N}_{2}$ has to be transformed to a bioavailable - or reactive - form (ammonia $\mathrm{NH}_{3}$ or ammonium $\mathrm{NH}_{4}{ }^{+}$) in order to be usable, a conversion, which requires a lot of energy to break the strong triple bond of the $\mathrm{N}_{2}$ molecule. Most $\mathrm{N}_{2}$ fixation is done by bacteria called diazotrophs, which have a specific enzyme called nitrogenase which combines gaseous nitrogen with hydrogen to produce ammonia. In the ocean, the main source of bioavailable nitrogen comes from $\mathrm{N}_{2}$-fixation by marine diazotrophs (cyanobacteria and proteobacteria) which are mainly present in warm waters in the low latitudes. The efficiency of $\mathrm{N}_{2}$-fixation depends on the environment, in particular, radiation, temperature, the presence of other nutrients (such as phosphate and iron), and $\mathrm{O}_{2}$ concentration. Smaller marine inputs of bioavailable nitrogen include atmospheric nitrogen deposition and riverine inputs.

Nitrification by soil or marine bacteria is the oxidation of ammonia $\left(\mathrm{NH}_{3}\right)$ into nitrate $\left(\mathrm{NO}_{3}\right.$ ). This oxidation is done in two separate steps: first the oxidation from $\mathrm{NH}_{3}$ to nitrite $\left(\mathrm{NO}_{2}^{-}\right)$by 
ammonia-oxidizing bacteria and archaea. Then the oxidation of $\mathrm{NO}_{2}^{-}$into $\mathrm{NO}_{3}{ }^{-}$by nitrite-oxidizing bacteria. Nitrification in the ocean takes place at the lower boundary of the euphotic zone where photosynthesis is limited by the low penetration of light, preventing the assimilation of nitrate by phytoplankton, and where remineralisation of organic matter increases nitrate concentration. In addition to this aerobic oxidation of ammonia into nitrate, anaerobic nitrification can also take place, called anammox (anaerobic ammonia oxidation).

Denitrification is the process that reduces $\mathrm{NO}_{3}{ }^{-}$to $\mathrm{N}_{2}$ gas, releasing it back to the atmosphere. It happens during respiration by anaerobic bacteria in low $\mathrm{O}_{2}$ conditions, and removes bioavailable nitrogen from the environment. In the process, intermediate gases are produced such as $\mathrm{N}_{2} \mathrm{O}$, which is a powerful GHG. In conditions where $\mathrm{O}_{2}$ is completely depleted, $\mathrm{N}_{2} \mathrm{O}$ instead of $\mathrm{NO}_{3}{ }^{-}$is respired into $\mathrm{N}_{2}$.

Ammonification is the production of $\mathrm{NH}_{4}{ }^{+}$by bacteria and fungi from organic nitrogen originating from dead plants or animals, or animal waste.

During nitrification and denitrification, $\mathrm{N}_{2} \mathrm{O}$, a greenhouse gas, is also produced. The sources of $\mathrm{N}_{2} \mathrm{O}$ come from both ocean and land. The sink of $\mathrm{N}_{2} \mathrm{O}$ is due to photochemical reaction with ozone in the stratosphere.

\subsubsection{Changes in the nitrogen cycle during glacial interglacial cycles}

Atmospheric nitrous oxide $\left(\mathrm{N}_{2} \mathrm{O}\right)$ has a large glacial-interglacial amplitude (Figure 12), with values of $\sim 200 \mathrm{ppbv}$ during glacial maxima and $\sim 270 \mathrm{ppbv}$ during interglacials including the Holocene and up to $280 \mathrm{ppb}$ during the interglacial 400000 years ago (MIS 11) (Schilt et al., 2010). Unlike $\mathrm{CO}_{2}$ and $\mathrm{CH}_{4}$, the concentration of $\mathrm{N}_{2} \mathrm{O}$ during the interglacial periods before $400 \mathrm{ka}$ is not lower than the concentration during the more recent interglacial. In addition, $\mathrm{N}_{2} \mathrm{O}$ shows a millennial variability similar to that of methane, with an amplitude very close to that of glacialinterglacial transitions (Schilt et al., 2013).

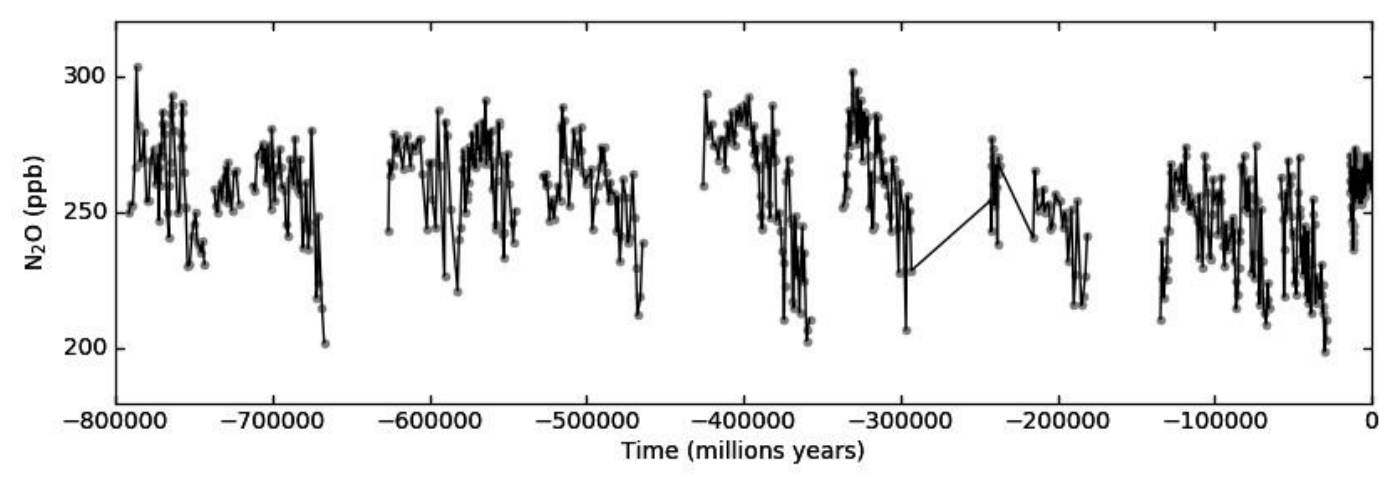

Figure 12. Evolution of $\mathrm{N}_{2} \mathrm{O}$ (ppb), over the last 800000 years. Data from Schilt et al., (2010).

There is little information available to explain the glacial-interglacial and millennial variations in $\mathrm{N}_{2} \mathrm{O}$. The natural cycle of $\mathrm{N}_{2} \mathrm{O}$ over these time scales is governed by two sources of approximately equal importance currently, an ocean source (estimated at $4 \pm 2 \mathrm{TgN} /$ year) and a terrestrial source (the natural part estimated at $7 \mathrm{TgN} /$ year), and by an atmospheric sink mainly linked to the photolysis of the $\mathrm{N}_{2} \mathrm{O}$ molecule in the stratosphere $(12 \mathrm{Tg} / \mathrm{yr})$. Modeling studies simulating atmospheric chemistry over the last few thousand years suggest that the $\mathrm{N}_{2} \mathrm{O}$ sink during the LGM was similar to now (Crutzen and Bruhl, 1993), resulting in a lifetime of $\sim 120$ years for 
$\mathrm{N}_{2} \mathrm{O}$ in the atmosphere. Therefore, it appears that variations in the sources are responsible for the changes in its atmospheric concentration during the Quaternary.

Isotopic data, in particular measurements of the ${ }^{15} \mathrm{~N}$ of $\mathrm{N}_{2} \mathrm{O}$, are used to separate the ocean source from the terrestrial source, as the former generally shows enriched isotopic signatures compared to the latter (probably due to a relatively stronger denitrification process in $\mathrm{N}_{2} \mathrm{O}$ production in an ocean environment). These data suggest that the ratio of ocean to land sources did not change over the last 33000 years (Sowers et al., 2003). These two sources appear to vary in phase with each other, with an increase of nearly $40 \%$ during warm periods compared to cold periods.

The mechanisms for explaining these variations are still largely hypothetical. The production of $\mathrm{N}_{2} \mathrm{O}$ in the ocean is generally linked to the presence of suboxic zones, low in oxygen, which are found directly below some of the major productive regions (east of the tropical Pacific, the Arabian Sea). In these zones deficient in dissolved oxygen, nitrates are used by the microorganisms as a source of oxygen during the denitrification reactions leading to the remineralization of the organic matter; nitrous oxide $\left(\mathrm{N}_{2} \mathrm{O}\right)$ is a by-product of these reactions. A decrease in the source of $\mathrm{N}_{2} \mathrm{O}$ during the glacial period could be the consequence of a shrinking of these zones, which would itself be a result of changes in ocean dynamics or local marine productivity leading to an increase in dissolved oxygen at the sub-surface. However, this hypothesis is only partially supported by reconstructions of paleoproductivity.

Another theory concerning the ocean source is related to the expansion of flooded surfaces on the continental shelves. Recent estimates suggest that a significant portion (between 0.6 and 2.7 $\mathrm{TgN}$ / year) of marine $\mathrm{N}_{2} \mathrm{O}$ production comes from the continental shelves. The significant drop in sea level $(-120 \mathrm{~m})$ during cold periods would have greatly reduced the flooded areas at the continental edges and thus the associated source of $\mathrm{N}_{2} \mathrm{O}$.

Several authors (Sowers et al., 2003, Flückiger et al., 2004; Schilt et al., 2013) also highlighted variations of around $40 \mathrm{ppbv}$ in the $\mathrm{N}_{2} \mathrm{O}$ concentration in the atmosphere in phase with Dansgaard-Oeschger events. These variations in $\mathrm{N}_{2} \mathrm{O}$ are substantially different in amplitude from variations in $\mathrm{CH}_{4}$. While methane recordings show a fairly strong correlation with insolation in the low and mid latitudes of the Northern Hemisphere, this is not the case for $\mathrm{N}_{2} \mathrm{O}$.

The concentration of $\mathrm{N}_{2} \mathrm{O}$ begins to increase before methane (during the warming phase in the Southern Hemisphere), and then the concentrations of the two gases reach their maximum at the peak of the hot phase of the D-O event. This information is compatible with the idea that both marine and terrestrial sources play an important part in the evolution of $\mathrm{N}_{2} \mathrm{O}$ : the marine source is stronger in the Southern Hemisphere, in phase with the warming period in the south, and the terrestrial source is stronger in the northern hemisphere, in phase with the warming period in the north.

So far, very little modelling work has focused on changes in the concentration of $\mathrm{N}_{2} \mathrm{O}$ in the atmosphere over the last hundreds of thousands of years. A simulation for the Younger Dryas episode suggests a combination of changes in the marine and terrestrial sources of $\mathrm{N}_{2} \mathrm{O}$ to explain the variations measured during this event. Simulations run by Schmittner and Galbraith (2008) show that changes in ocean circulation play a major role $\mathrm{N}_{2} \mathrm{O}$ variations. A reduction of the AMOC leads to decreased productivity and better ventilation resulting in increased subsurface oxygen concentrations, which explains the decrease in $\mathrm{N}_{2} \mathrm{O}$ production.

\subsection{Oxygen cycle}

\subsubsection{The oxygen cycle and its ocean component}

Atmospheric free oxygen does not directly impact climate since it does not absorb infrared radiations. Despite this fact, the cycle of oxygen has gained lots of attention primarily because of its 


\section{Page 21}

tight relationship with life on Earth. Indeed, the main source of free oxygen comes as a waste product of photosynthesis by plants on land and phytoplankton in the ocean. The main oxygen sink is due to respiration and/or remineralization of organic matter by almost all living organisms, which consume di-oxygen and release carbon dioxide. Other minor sources include the photolosyis of $\mathrm{N}_{2} \mathrm{O}$ and $\mathrm{H}_{2} \mathrm{O}$ in the atmosphere, whereas oxygen sinks are numerous and include a number of oxidation and chemical weathering pathways (see Walker, 1980, for a review of the global oxygen cycle).

Many studies have examined the oxygenation of the Earth's atmosphere over geological time scales, focusing for example on the Great Oxidation Event 2.45 billion years ago (e.g., Holland, 1984) or on the variations of atmospheric $\mathrm{O}_{2}$ over the Phanerozoic (Berner et al., 2003). Over the last million years, the consensus is that the atmospheric concentration of $\mathrm{O}_{2}$ has been very stable due to the very long residence time of $\mathrm{O}_{2}$ in the atmosphere-ocean system (on the order of two million years, Catling and Claire, 2005).

The oceanic component of the oxygen cycle has been however much more variable over glacial-interglacial cycles (Jaccard and Galbraith, 2012). This is due to the fact that the oceanic reservoir of oxygen is much smaller than the atmospheric one $\left(225 \mathrm{Tmol} \mathrm{O}_{2}\right.$ in the ocean vs. $3.810^{7}$ Tmol of $\mathrm{O}_{2}$ in the atmosphere), and that dissolved oxygen concentrations in the ocean are very heterogeneous, with $\mathrm{O}_{2}$ concentrations ranging from 0 to almost 400 micromol/L. A map of $\mathrm{O}_{2}$ concentrations at mid ocean depth illustrates this heterogeneity (Figure 13), with $\mathrm{O}_{2}$-enriched waters at high latitudes and $\mathrm{O}_{2}$-depleted waters in the Eastern Tropical Pacific and in the Northern Indian Basin (depicting the so-called Oxygen Minimum Zones).

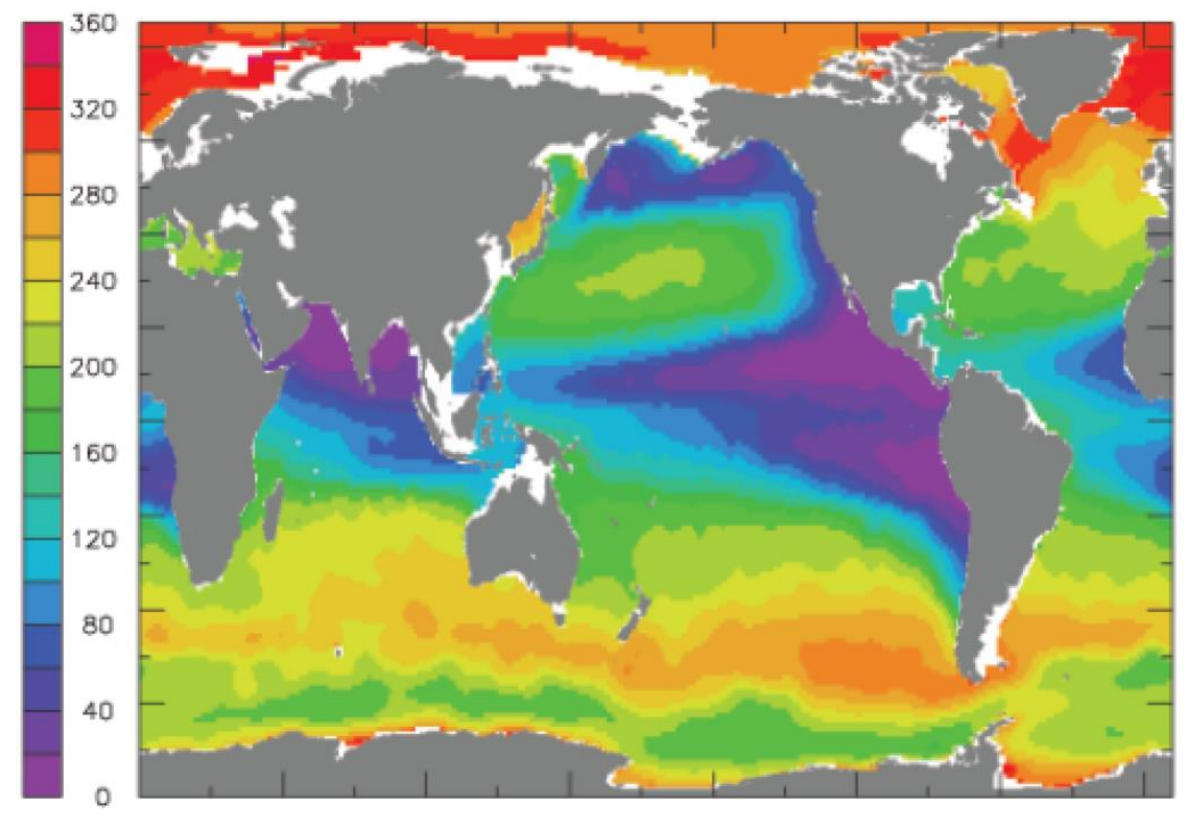

Figure $13 . \mathrm{O}_{2}$ concentrations at mid ocean depth (averaged over 200 to $600 \mathrm{~m}$, in micromole/L) from the World Ocean Atlas (2009) (Garcia et al., 2010).

The oxygen content of the ocean results from a fine balance between the consumption of oxygen by respiring organisms feeding on organic matter sinking from the surface, and the supply of $\mathrm{O}_{2}$-rich waters coming from the surface of the ocean through ocean ventilation.

Because oxygen is a fundamental resource for aerobic organisms, the distribution of oxygen 
in the ocean has a large imprint on marine life, shaping for example the habitat of large fish such as tunas or billfishes (Stramma et al., 2012). Over the past decades, observations have shown that oxygen concentrations have decreased in the open ocean in many ocean regions and that the tropical oxygen minimum zones (OMZs) have likely expanded (Rhein et al., 2013). The mechanisms involved are a decrease in the oxygen solubility due to ocean warming and the combination of reduced ocean ventilation and increased stratification that prevents the penetration of oxygen into the interior of the ocean. These mechanisms are very consistent with the recent global warming trend, suggesting that deoxygenation will continue with future anthropogenic climate change. Indeed, climate models do simulate a clear deoxygenation trend with global warming, with an oceanic loss of oxygen of a few percent at the end of the $21^{\text {st }}$ century (Bopp et al., 2013). At the regional scale however, there is yet no consensus on the evolution of subsurface oxygen levels, with very large model uncertainties.

\subsubsection{Ocean oxygenation at the Last Glacial Maximum}

The past record of ocean oxygenation during glacial-interglacial cycles provides a complementary perspective on how the oceanic oxygen content may respond to climate change or climate variability. The reconstruction of past ocean oxygenation relies on sedimentary proxies of bottom water oxygenation. The most common proxies for ocean oxygenation are based on the presence of sediment laminations (that testify very low levels of bottom water oxygen levels), on redox sensitive trace metals (such as uranium and molybdenum) and on benthic foraminifera assemblages.

Despite recent progress on the developments of new proxies and the multiplication of the application of such methods to a growing number of sediment cores, the indications of past ocean oxygenation over the last glacial-interglacial cycles portrayed by these records stay very qualitative and mostly apply to the last deglaciation (Jaccard and Galbraith, 2011). Overall, marine sediments indicate an oxygenation of the deep ocean throughout the last deglaciation and an expansion of lowoxygen waters in the upper ocean. These changes seem quite consistent across all ocean basins (Figure 14). 


\section{LGM to Holocene}

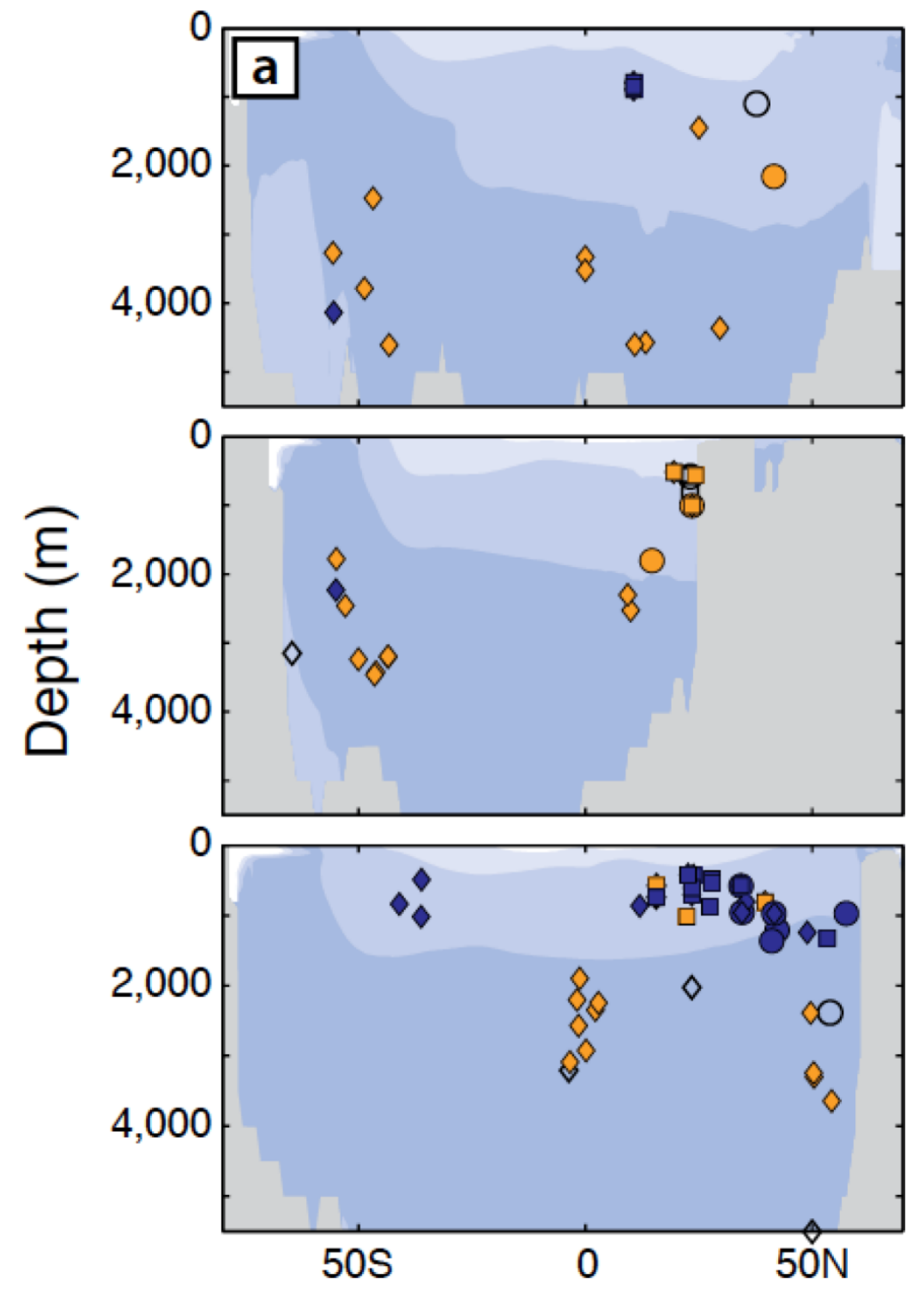

Figure 14: Changes in ocean oxygenation between the Last Glacial Maximum and the Early Holocene for the Atlantic (top), Indian (middle) and Pacific (bottom) basins. The symbols refer to the different proxies used to infer past oxygenation (squares corresponding to laminations, circles to foraminifera species assemblages, and diamonds to redox-sensitive trace metals). Blue shadings indicate a relative decrease in oxygenation and orange shadings a relative increase in oxygenation from the LGM to the early Holocene. From Jaccard et al. (2014).

The mechanisms responsible for such changes are still debated (Jaccard et al., 2014; Bopp et al., 2017). In the sub-surface ocean for example, the decreasing trend in oxygen levels during the deglaciation could be due to an increase in carbon export from the surface layers that would have increased oxygen consumption in the subsurface ocean (Jaccard and Galbraith, 2012), but also to a decreased ventilation of sub-surface layers in response to changes in oceanic circulation (Bopp et al., 2017). 


\subsubsection{Ocean Oxygenation in the Mediterranean Sea: The case of Sapropels}

\section{Definition and overview}

Sapropel events are clearly identified in marine sediments. They are characterized by an organic rich layer sedimentation, mainly found in the eastern basin (Figure 15). The peculiarity of this sedimentation suggests an anoxic environment allowing the organic matter preservation- due to the shutdown of the thermohaline ventilation (Möbius et al., 2010) and/or an enhanced biological productivity leading to an increased oxygen consumption (Martinez-Ruiz et al., 2000).

Sapropel events have been largely described and investigated since they have been identified in the middle of the 20th century (Kullenberg, 1952). Since the closure of East Tethys seaway 14 million years ago (Hamon et al., 2013), the only connection between the Mediterranean basin and the global ocean has been the Gibraltar straight. This semi-enclosed configuration favored sapropel events that occurred with a frequency of 21,000 years (Emeis et al., 2003).
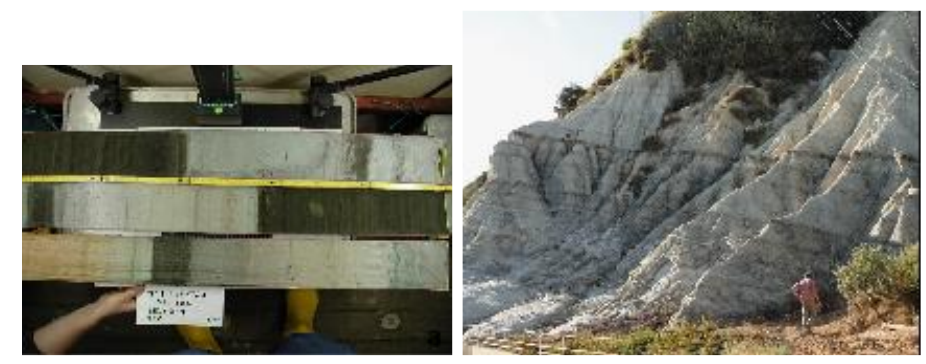

Figure 15. Left, sapropels within a sediment core recovered in 2001 during RV Meteor cruise M513 (Hemleben et al., 2003) (photograph by Eelco.J. Rohling and Kristian.C. Emeis). Right, late Pliocene sapropel layers outcropping at Punta Piccola (Plancq et al., 2015).

\section{Large variability in contexts, developments and processes associated with sapropels occurrences}

There is a large variability in the imprints (strength, extension, duration) of these sapropels (see Rohling et al. (2015) for a review). For example the carbon organic content levels in sapropels typically range between 1 and $10 \%$ with a large variability, for instance sapropel S5 occurring during the last interglacial reached values from 7 to $15 \%$ (Grant et al., 2012) and Pliocene sapropel may reach 30\% (Nijenhuis and De Lange, 2000).

Whereas pacing of sapropel is strongly correlated to precessional cycles, there are major differences in preconditioning water masses that favor the occurrence of sapropels. Superimposed to this variability, the triggering of sapropel has been shown to be several thousand years after the maximum summer insolation in the northern hemisphere. Ziegler et al. (2010) inferred a recurrent lag between the northern hemisphere insolation maximum and sapropel deposition.

Sapropels typically lasted between $\sim 3$ to $\sim 8$ kyrs. For instance, durations of $\sim 4.4, \sim 4.0, \sim 6.2$, and $\sim 7.4$ kyr for S1, S3, S4, and S5, respectively has been attributed by different methods (Grant et al., 2012) Despite a large variability in time and space of benthic recolonization at the end of a sapropel. The end of enhance monsoon seems to mark a sharp and widespread (basinwide) onset of deep water oxygenation due to resumption of strong convective deep-water formation.

Sapropels are more common in the eastern Mediterranean (east of the Strait of Sicily) than in the western Mediterranean, where they are also known as Organic Rich Layers (ORLs) (Rogerson et al., 2008). 
As suggested by Rohling et al. (2015), the eastern Mediterranean is more sensitive to development of deep-sea anoxia than the western Mediterranean, because of differences in the efficiency of deepwater renewal.

For a long time, the relationship between insolation changes associated with precession cycles and impacts on hydrological changes through fresh water inputs has been invoked as causal link to explain sapropel occurrences (Rossignol-Strick, 1982). Nevertheless, there are many different contexts in, which sapropels have occurred since the Miocene (Rohling et al., 2015). For instance, the role of the cryosphere was certainly different during Pliocene and Pleistocene. For Quaternary, it has been shown that, superimposed to the major effect of African monsoon and enhancement of freshwater from the Nile river, other forcing factors have to be accounted for. The imprint of glacial-interglacial cycle and associated sea level changes has been shown to contribute strongly for sapropel occurring during deglaciation as S1 (Rohling et al., 2015, Grimm et al., 2015)

\section{Most recent advance on S1 sapropel modeling:}

Modeling represents also a unique tool to investigate the responses of the Mediterranean basin to different external forcing factors from insolation changes to associated hydrological perturbations that may produce sapropel events.

Two important developments have been down recently concerning sapropel modeling: much longer simulation and much higher spatial resolution.

Superimposed to precession cycles, since one million years the $100 \mathrm{ky}$ glacial-interglacial cycle has also affected sapropel occurrence (Köng et al., 2017). Recent modeling studies (Grimm et al., 2015) aimed to simulate the $\mathrm{S} 1$ from its onset. A more specific scenario, involving a preconditioning of cold and poorly salted water coming from the last Heinrich event, was suggested as a possible cause for the $\mathrm{S} 1$ formation.

Another important issue is to reach high resolution to capture convection patterns in the Mediterranean basin. Using a coupled AOGCM (Atmospheric-Ocean Global Circulation Model) including a regional Mediterranean Sea model (1/8 ${ }^{\circ}$ much higher than previously used), Vadsaria et al. (2019) have revisited the impact of Nile hosing fresh water increase on triggering sapropel S1. This improvement allows for better simulating the intermediate and deep convection occurring in winter (Adloff et al., 2015).

Moreover, the simulation of oceanic tracer as $\mathrm{Nd}$ allows one to validate changes in ocean dynamics (Ayache et al., 2016).

\subsection{Sulphur}

The sulfur cycle is of interest to climatologists because it leads to the formation of sulfuric acid $\left(\mathrm{H}_{2} \mathrm{SO}_{4}\right)$, a submicronic aerosol that reflects solar radiation efficiently (direct effect) and which, due to its highly hygroscopic nature, has a physical influence on clouds (indirect effect). It is formed in the atmosphere by the oxidation of $\mathrm{SO}_{2}$ whose emission level through the combustion of fossil reserves is 35-45 Tg per year. The IPCC estimates that due to the increase in sulfate aerosols in the atmosphere, anthropogenic emissions of $\mathrm{SO}_{2}$ could be responsible for a radiative forcing of $0.4 \mathrm{~W} / \mathrm{m}^{2}$, an opposite forcing but equivalent to about one third of the radiative forcing linked to the increase of $\mathrm{CO}_{2}$ in the atmosphere $\left(+1.2 \mathrm{~W} / \mathrm{m}^{2}\right)$. However, as noted above, the comparison between these two values is of limited significance since the forcing of the aerosol may, for example, be much greater over heavily anthropized regions of the northern hemisphere. Moreover, the temporal evolution of anthropogenic $\mathrm{SO}_{2}$ emissions varies greatly from one continent to 
another: emissions reached a peak in the 1980s in Western Europe and the USA, while an acceleration of their emissions is underway in India, for example. The sulfur cycle in the atmosphere also involves two major natural sources, volcanic activity and marine DMS biogenic emissions. An important dimension of the latter source is its potential response to climate conditions, a hypothesis proposed by Charlson, Lovelock, Andreae and Warren, four authors of a well-known article in Nature in 1987, proposing that DMS emissions produced by plankton may act as a climate regulator (Figure 16). Responses by the marine biosphere (changes in primary productivity, phytoplankton speciation, stratification of surface ocean layers, wind patterns, etc.) to the current climate change are thus possible. Its direction and magnitude remain uncertain, but some ocean-atmosphere models incorporating an ocean biology module, coupling sulfur and carbon, suggest that a $40 \%$ increase in DMS emissions could occur in the $40^{\circ} \mathrm{S}$ zone in response to a doubling of $\mathrm{CO}_{2}$ content and to the associated climate change (Bopp et al., 2003b).

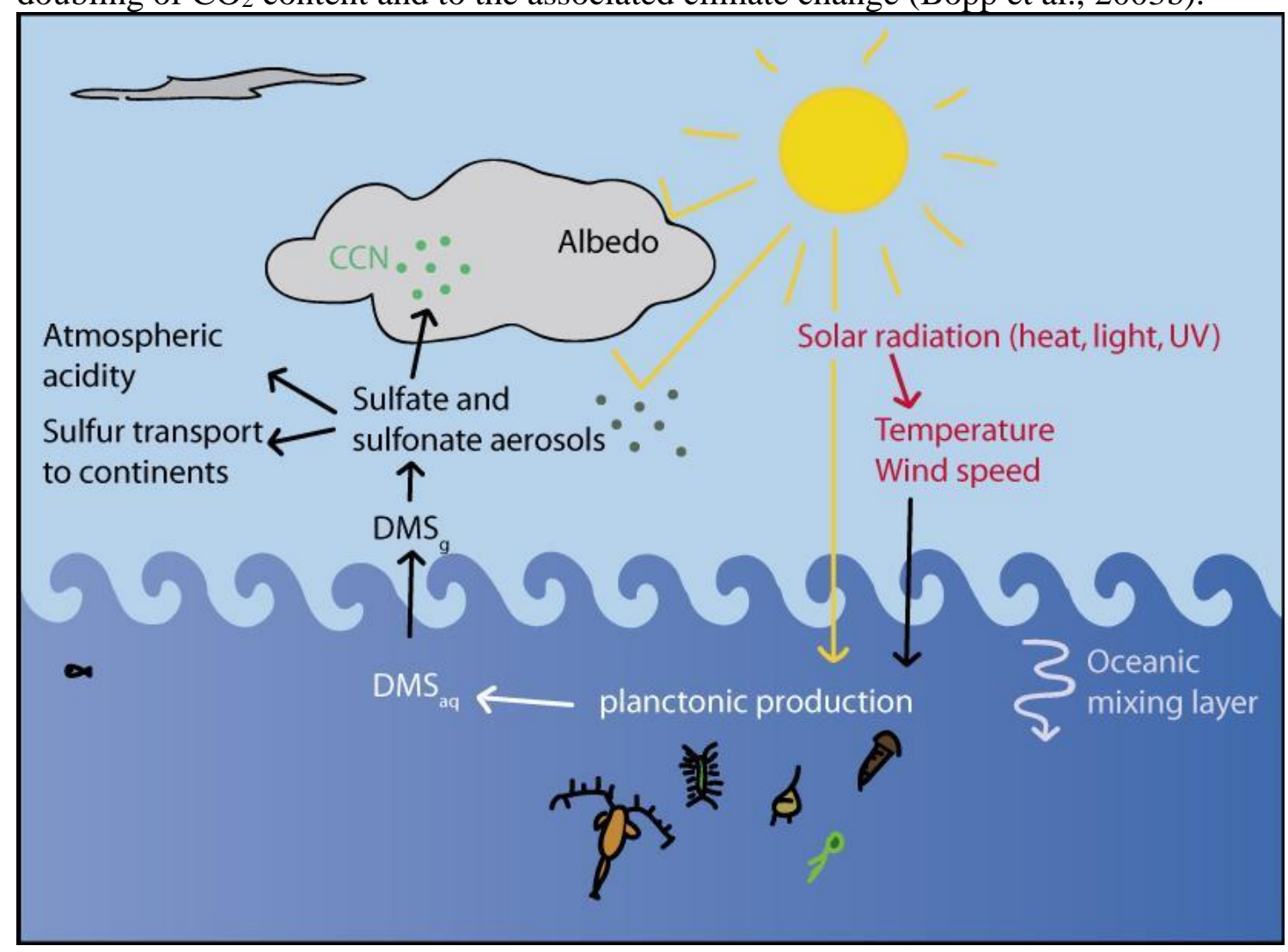

Figure 16 - Feedback mechanisms linking our planet's climate to DMS emissions from the ocean (adapted from Charlson et al., 1987).

The idea of examining the relationship between marine biogenic sulfur emissions and past climate is the motivation behind many ice core studies. Given that sulphate in the atmosphere has several origins, the first attempt at reconstituting marine biogenic emissions was made by examining the MSA content of ice (Saigne and Legrand, 1987). This study of the last climate cycle in the Vostok ice core indicated an increase in MSA deposition fluxes by a factor of almost three between an interglacial period and the final stage of an ice age, despite the fact mentioned previously that sulphate flux has shown little variation in the past (Legrand et al., 1991). Since isotopic studies of sulfur undertaken on sulphate have subsequently clearly established that DMS emissions are the major source of sulphate in Antarctica, a contradiction therefore appeared between the two proxies of DMS emissions, with the MSA suggesting an increase in DMS emissions, but not in sulphate. The hypothesis of an increase in DMS emissions during the glacial period seemed reasonable given that the phytoplankton species that emits a lot of DMS (Phaeocystis) has a particular affinity with sea ice. 
The difference between the sulphate and MSA records remains unclear to date. The atmospheric studies carried out over the last few years in Antarctica demonstrate the complexity of the problem. Although the atmospheric levels of the three sulfur species coincide well over time with the DMS concentrations in the Southern Ocean, the interannual variability observed in the Southern Ocean does not show any straightforward connection with annual sea ice cover (Preunkert et al., 2007). These measurements also reveal intricate processes involving photochemistry and atmospheric dynamics which makes the link between the two sulfur species and DMS very complex. These studies continue to be pursued actively due to the fact that, to date, only from ice can past variability in marine biogenic emissions potentially be reconstructed, since organisms like Phaeocystis do not leave any traces in marine sediments. The issue is important because it contributes to our understanding of the feedback taking place in high latitudes (regions highly sensitive to global changes in climate), involving complex processes between marine biology, sea ice, and climate.

\subsection{Aerosols and dust}

Aerosols are small liquid or solid particles, ranging from a few $\mathrm{nm}$ to $100 \mu \mathrm{m}$, in suspension in the atmosphere. Natural aerosols include desert dust, sea salt, carbonaceous, sulphur and nitrogen species, largely emitted from dry and vegetated landscapes, the oceans, and volcanoes (Carslaw et al., 2010). Primary aerosols are emitted directly from the surface of the Earth, whereas secondary aerosols are formed from gaseous precursors in the atmospheric environment. Aerosols are washed out by precipitation, or removed by gravitational settling and dry deposition, so that their lifetime in the atmosphere is short, a few days only - except when they reach the stratosphere, where they can stay for a few years, as can happen during giant volcanic eruptions. Therefore, unlike well-mixed GHGs, aerosols are considered to be short-lived climate forcing agents, and their impacts are characterized by a strong regional component (Boucher et al., 2013). Aerosol emissions vary depending on surface climate conditions; on the other hand, aerosols impact the climate system themselves, though direct and indirect (cloud-mediated) interactions with the atmospheric radiation budget, by changing the surface albedo, as well as by means of indirect impacts on global biogeochemical cycles (Mahowald et al., 2017).

Size, shape and composition define the specific interactions of aerosols with radiation, including absorption and scattering of shortwave (solar) and longwave (terrestrial) radiation. The scattering of shortwave radiation results in cooling, but absorption can lead to warming when it is above a highly reflective surface. Through their absorption of outgoing longwave radiation, aerosols also behave like GHGs. For some aerosol species, one particular effect is dominant, in other cases, opposing effects coexist. Considering the variability of aerosol spatial distribution, the coexistence and mixing of different aerosol species, and the diversity of aerosol-radiation interactions, it is clear that direct impacts of aerosols on climate constitute a complex problem (Boucher et al., 2013).

Aerosols also interact with clouds. Changes in relative humidity linked to the vertical stability of the atmospheric column and the surface evapotranspiration balance, occurring as a rapid adjustment to direct aerosol forcing, can influence cloud formation. This is called the semi-direct effect. The indirect effects, on the other hand, involve aerosols acting as cloud condensation $(\mathrm{CCN})$ or ice nuclei (IN), which means that water or ice aggregates around them. This modifies the type, extent and lifetime of clouds. For example, the presence of aerosols leads to smaller but more numerous droplets, which yields a more reflective cloud than it would be without aerosols. This also means that clouds formed with aerosols will have a longer lifetime since the droplets are smaller and won't reach the critical size for precipitation. The indirect effect can result in warming or cooling depending on the altitude where clouds are formed. Because the effect of aerosols on radiation and on clouds is complex and depends on many parameters, it remains one of the main sources of uncertainties in models (Boucher et al., 2013). 
In addition, aerosols depositing back to the surface can also modify the albedo. This is the case of dust, and especially black carbon; they can cause snow and ice to darken, which reduces the albedo and leads to warming.

In virtue of their composition, aerosols also act as carriers of specific elements, such as nitrogen, phosphorus, sulphur, and iron, which are linked to important biogeochemical cycles, including the carbon cycle (Mahowald et al., 2017). In particular, phosphorus and iron are linked to the dust cycle, and the peculiarity is that windblown inputs can be fundamental to the mass budgets of those elements in remote regions, far from the dust sources. For instance, dust-borne phosphorus from North Africa replenishes the pool of this element in the Amazon, where the loss by fluvial erosion would otherwise deplete it, with implications for the rainforest. Iron, on the other hand, is a micronutrient for marine ecosystems. Because its sources are the continents, remote marine areas are depleted in this element. Where the abundance of macronutrients such as nitrogen and phosphorus is accompanied by a relative scarcity of iron, which limits the primary production at the ecosystem level, i.e. in High-Nutrient Low-Chlorophyll (HNLC) areas, dust-borne inputs of iron become of great importance in sustaining algal blooms - this is notably the case of the Southern Ocean (Jickells et al., 2005).

\subsubsection{Natural aerosols: overview}

In this section we will briefly describe the main natural aerosol types. Note that mineral dust and sea salt are still the most abundant primary aerosol species by mass in the present day atmosphere.

Mineral (desert) dust (Figure 17) is emitted into the atmosphere in response to wind erosion of the surface, in dry and semi-dry areas, with low vegetation cover. Far-travelled dust particles are mostly clays and fine silts below $10 \mu \mathrm{m}$ in diameter, and are composed mainly of silicates, along with carbonates, gypsum, and metal oxides. Dust aerosols interact with both solar and terrestrial radiation, and act as ice nuclei in mixed phase clouds. As already mentioned, dust deposition on the surface can reduce snow albedo and impact on the carbon cycle through phosphorus and iron mediated interactions with global biogeochemical cycles. 


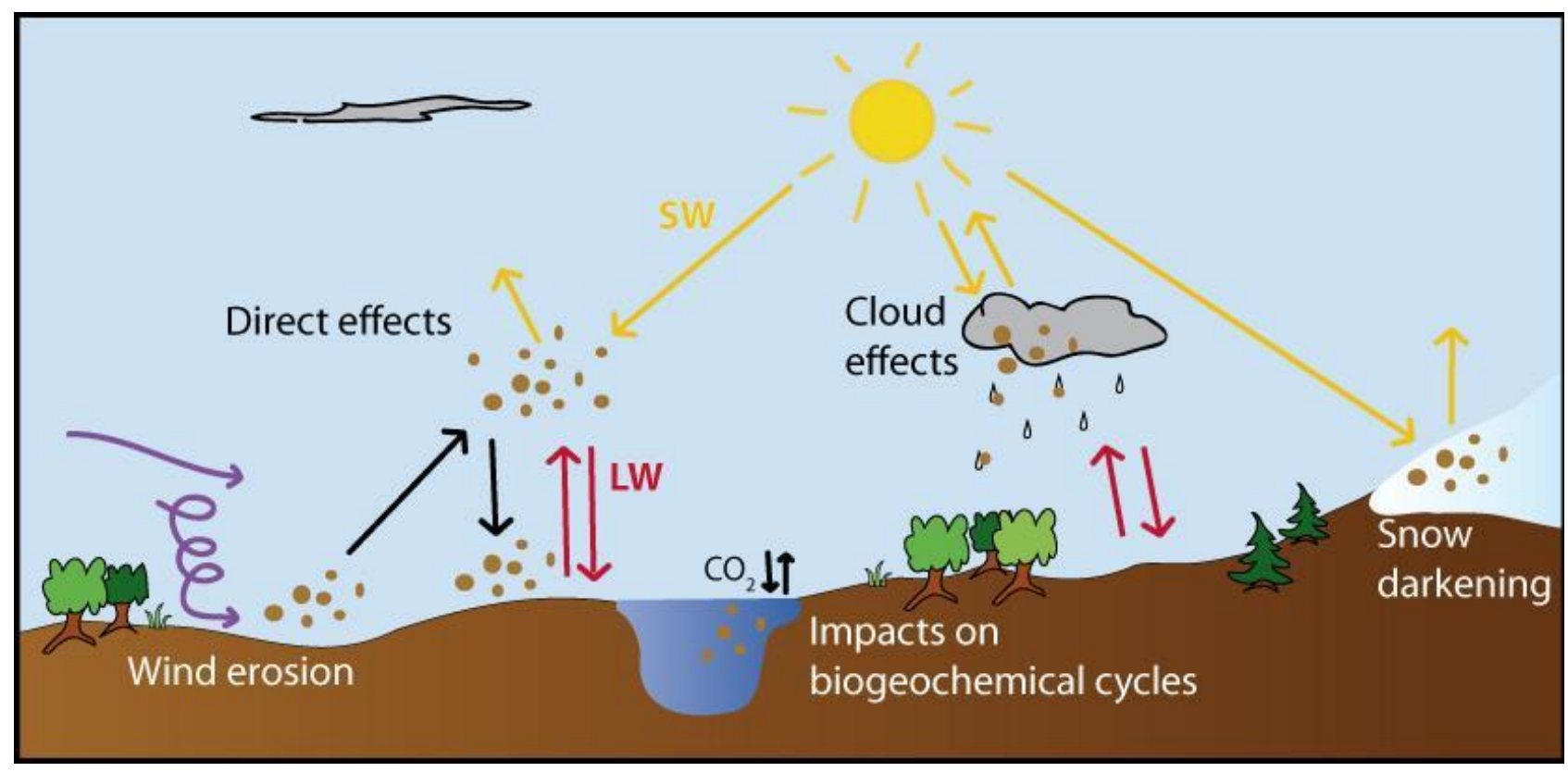

Figure 17. Overview of the dust cycle and its interactions with the climate system.

Land vegetation is a source of primary biogenic aerosol particles (PBAP), in the form of fungal spores, viruses, bacteria, pollens and plant debris, as well as aerosol precursors such as isoprene and other volatile organic compounds (VOC), which result in the formation of secondary organic aerosols (SOA). Wildfires are responsible for the emissions of particulate organic matter and black carbon. Particulate carbonaceous aerosols have a slight net cooling effect in the atmosphere, and play a role as cloud condensation and ice nuclei. Black carbon is a strongly absorbing aerosol, associated with snow darkening and has a warming effect on the atmosphere.

Wetlands emissions of ammonia, and $\mathrm{NO}_{\mathrm{x}}$ produced by biomass burning, biogenic soil emissions, stratospheric injection and by the interaction of lightning with atmospheric $\mathrm{N}_{2}$, are the main precursors to nitrogen aerosol species, which overall have a moderate net cooling effect in the atmosphere, and may impact on biogeochemical cycles.

Volcanic emissions of $\mathrm{SO}_{2}$ are one of the primary sources of precursors for the formation of natural sulphate aerosols, which are characterized by a strong cooling impact on the atmospheric radiation, and they are very efficient $\mathrm{CCN}$. Volcanic eruptions can also eject glass shards and ash, which can leave a mark by depositing as tephra layers - very useful stratigraphic markers.

Wind stress on the surface of the oceans drives aerosol emissions at the sea-air interface, where bubbles bursting within breaking waves eject sea sprays composed mostly of sea salt (dominating the super-micron fraction), along with organic particles (concentrated in the submicron fraction). Sea salt and some organic particles are also emitted from the surface of sea ice, where these form frost flowers during the process of brine rejection that accompanies the freezing of seawater. Sea salts tend to cool the atmosphere, and because of their high hydroscopicity, they act as CCN (O’Dowd et al., 2007). Oceans are also a major source of precursors of sulphate aerosols, in the form of biogenic emissions of dimethylsulfide (DMS) that is then oxidised to sulphuric acid and methane sulfonic acid (MSA) in the atmospheric environment (Legrand and Mayewski, 1997). 


\subsubsection{Dust variability and impacts on past climates}

The past history of the dust cycle is imprinted in natural archives such as ice, marine sediments, loess / paleosol sequences, and peat bogs. Dust has the greatest preservation potential among all aerosol species, because it is essentially insoluble, and traces of it are present in a variety of environments all around the globe. In general, we can obtain a paleodust record from natural archives when the following conditions are met: there is preservation of the deposition signal; we can establish a chronology; and we are able to separate eolian contributions from the sedimentary matrix.

The fifty-meter thick loess deposits of China and North America are probably the most spectacular evidence of how the dust cycle is capable of shaping immense landscapes - loess deposits cover $10 \%$ of the emerged landmasses. Loess accumulation in China has been an ongoing process for over 20 million years, since the uplift of the Tibetan plateau caused widespread aridification of central-eastern Asia. Beyond that, little is known, although isolated information on deep paleoclimate conditions at least dating back to the Paleozoic ( $\sim 500$ million years ago) can be derived, based on the analysis of geologic formations whose origin can be ultimately linked to eolian sedimentation.

We have a better picture of the global dust cycle on Quaternary time scales, especially since the late Pleistocene. From polar ice core records we know that a strong dust-climate coupling was a persistent feature at least over the last eight glacial-interglacial cycles; colder climate states are characterized by increased dustiness, as shown by the milestone paleoclimate records from the Vostok and EPICA Dome C (EPICA Community Members, 2004) ice cores from Antarctica (Figure 18). Preservation of stratigraphy and chronologies based on numerical (absolute) dating methods allow for a more detailed reconstruction of the last glacial-interglacial cycle. In particular, global compilations of paleodust records based on dust mass accumulation rates provide a quantitative metric to compare paleodust records from different natural archives, and constitute a benchmarking tool for models (Kohfeld and Harrison, 2001). 

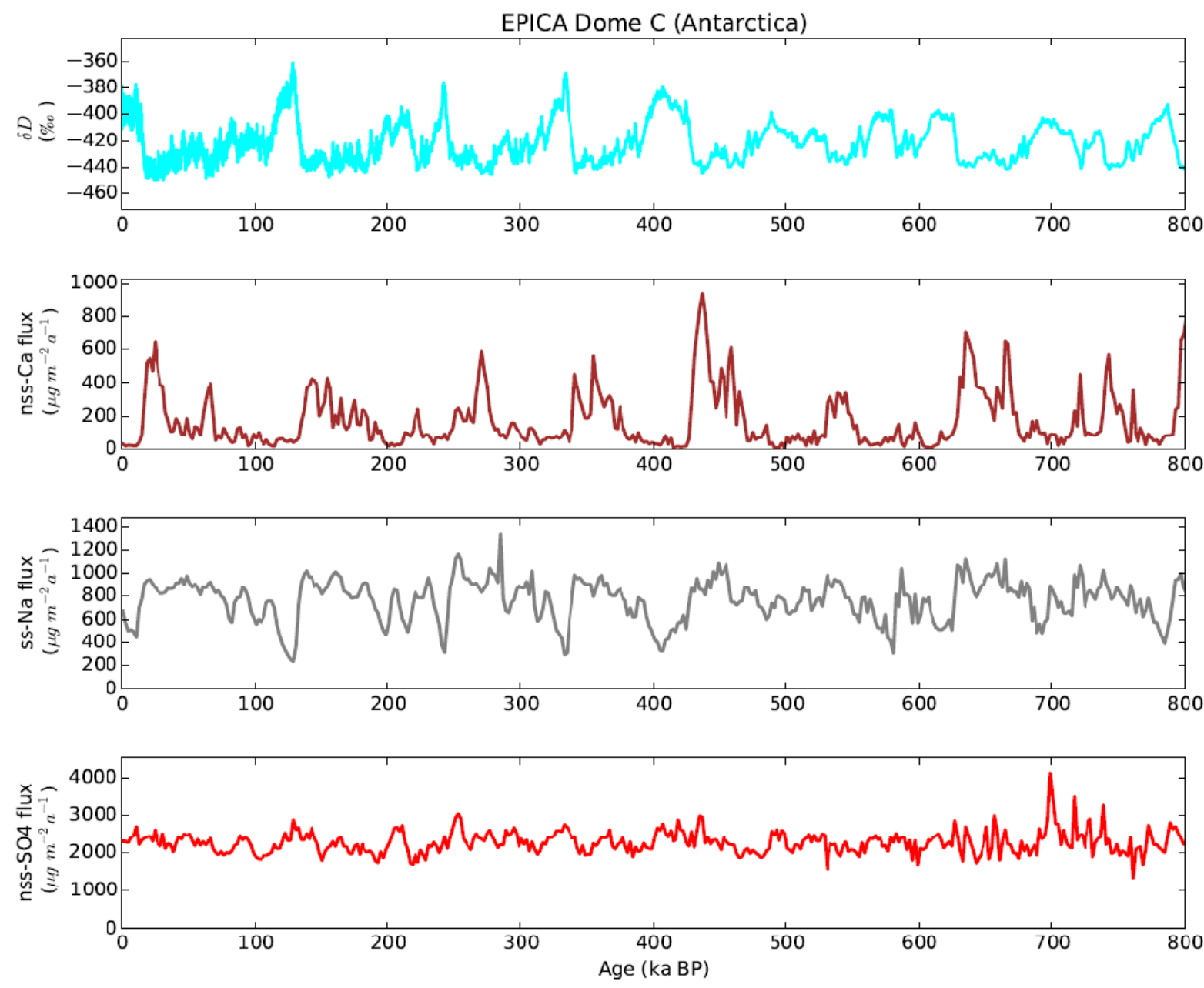

Figure 18. Overview of aerosol (nss-SO $\mathrm{SO}_{4}{ }^{2-}$ as a proxy for sulfate aerosols, ss-Na for sea salt, and nss-Ca for dust) deposition fluxes from the EPICA Dome C ice core (Wolff et al., 2006), Antarctica, along with indicators of global climate, i.e. deuterium excess (Jouzel et al., 2007).

During the LGM, global dust emissions were enhanced by a factor of 2 to 4 , and the increase in dust deposition in high latitudes was even by a factor of 10 or more. A combination of changes in dust source areas and transport patterns, driven by the large-scale atmospheric circulation, shaped the geographical variability in dust cycle dynamics. The sharp decline in dust deposition to Antarctica paralleling the rise in atmospheric $\mathrm{CO}_{2}$ levels, led oceanographer John Martin ("Give me a tanker of iron, and I will give you an ice age"), in the late eighties, to formulate the famous iron hypothesis: the glacial increase in dust-borne iron inputs to the Southern Ocean may have stimulated the ocean biological pump, resulting in an increased productivity in HNLC areas and subsequent carbon sequestration in the deep ocean (Jickells et al., 2005). State of the art ESMs suggest that this mechanism may have been responsible for a decrease of $\sim 20 \mathrm{ppmv}$ of atmospheric $\mathrm{CO}_{2}$, out of $80 / 100$ ppmv - the overall decrease in $\mathrm{CO}_{2}$ concentrations during the LGM measured in ice cores. On the other hand, the impact of the increased dust burden on atmospheric radiation is estimated by models to be at least $-1 \mathrm{~W} / \mathrm{m}^{2}$ globally, compared to $-6 \mathrm{~W} / \mathrm{m}^{2}$ forcing by reduced GHGs atmospheric concentrations and changes in surface albedo from decreased sea levels and the growth of ice sheets in the Northern Hemisphere. Nonetheless, this figure might hide much larger dust impacts of the opposite sign, with strong cooling downwind of the major dust sources, and warming over the bright, glaciated Arctic regions (Albani et al., 2018). 
During the course of the entire glacial period, millennial scale variability expressed by DansgaardOeschger and Heinrich events in the $\delta^{18} \mathrm{O}$ record in Greenland ice cores, is almost paralleled by variations in dust deposition rates, with colder phases associated to dustier conditions (Rasmussen et al., 2014). The same picture emerges from the corresponding alternation of stadial/interstadial periods in Antarctica (EPICA Community Members, 2006).

The deglaciation followed, characterized by a non-monotonic increase in global temperatures and $\mathrm{CO}_{2}$, mirrored by decreasing dust levels in both hemispheres. While the Holocene was initially described as a relatively flat period in terms of dust, based on polar records, in the last three decades, a few studies of North Atlantic sediment cores highlighted the large variability in North African dust emissions; a reduction by a factor 2 to 5 corresponded to the "Green Sahara" phase of the Early and mid-Holocene, characterized by an enhanced summer monsoon, compared to the drier late Holocene after $\sim 5 \mathrm{ka} \mathrm{BP}$. The possible (positive or negative) feedbacks between the monsoon system and variations in the North African dust cycle are a subject of study by the modelling community (Albani et al., 2015).

Ironically, we know relatively less about the more recent past. Marine sediments and loess profiles generally can't achieve a temporal resolution fine enough to resolve the last millennia, and often surface layers of loess/paleosol deposits are disturbed by agricultural practices, as they tend to be very fertile soils. Ice cores do provide this kind of temporal resolution, but we still have very little data. The top meters of polar cores, corresponding to this time frame, are actually made of firn, which complicates the analysis because of the risk of contamination of the samples. Alpine ice cores, on other hand, allow the analysis of dust concentration and can have good chronologies for the last few decades, but reliable, quantitative estimates of dust mass accumulation rates are hampered by the extreme spatial variability of snow accumulation and post-depositional processes. Therefore, we do not have a clear pre-industrial reference state for dust (Carslaw et al., 2010). A few studies trying to address dust trends during the twentieth century yield contrasting results; a generally increasing trend over parts of the last century suggested by some authors may have "masked" a fraction of global temperature increase, due to the net cooling effect of dust.

\subsubsection{Other aerosol species in past climates}

There is much less information about other aerosol species in the past; unlike dust, solubility and volatility limit the preservation of most species in many environmental settings, and pose additional analytical challenges. Most of the information we have is from ice cores (Wolff et al., 2006, Preunkert and Legrand, 2013).

$\mathrm{Na}^{+}$is a stable proxy for sea salts. Yet, we do not really have information from lower latitudes; sea salt records from polar ice cores (Figure 18) show, similar to dust, increased deposition rates in glacial climates, by a factor 3 to 5 in Antarctica and 1.5 to 3 in Greenland. It is not fully clear to what extent this was due to an increase in emissions or transport from open waters, rather than to the expanded sea ice source, although the latter seems to be the dominant factor. Increases in sea salts could have had a negative forcing, via direct and indirect effects, on the atmospheric radiation budget.

Sulphur and nitrogen aerosol species present more important issues with preservation, and are more difficult to interpret. The baseline sulphate records from polar ice cores (Figure 18), mainly derived from DMS emissions, show a flat signal in Antarctica and some variability in Greenland. This has dampened some early enthusiasm for the idea that DMS could be a dominant 
feedback in driving glacial-interglacial variability, given the strong cooling effects associated with sulphate aerosols. Sulphate concentration spikes are associated with inputs from large volcanic eruptions, and are sometimes associated with the presence of tephra. In certain cases, a lag of one or two years was observed in the peaking of the two signals, suggesting a longer stratospheric residence time of sulphates. There are no clear trends in volcanic activity on late Quaternary time scales, although several volcanic spikes marked the deglaciation.

There is very little direct information on carbonaceous aerosols from ice cores on late Quaternary time scales. Some data is available on paleofire proxies, such as ammonium or levoglucosan, which can be combined with information form charcoal, preserved in paleosols, peat bogs, and lakes - on the other hand, an indicator of the source of the aerosols and precursors, rather than the sink. Finally, the variation of pollen assemblages archived in lakes and peat can provide information on the state of past vegetation, which is a source of many aerosols and precursors. The general picture is that land biogenic and fire emissions during the last glacial period were lower than today, at least at high latitudes, which is consistent with a drier and colder climate, and the reduction of vegetated areas linked to the growth of the large ice sheets in North America and Eurasia. More data on the recent past cores can be found in snow and ice, showing the influence of anthropic activities on carbonaceous, sulphate and nitrogen aerosols (Preunkert and Legrand, 2013).

\subsection{Conclusion}

In this chapter, we have looked at the major biogeochemical cycles that interact with climate: carbon $\left(\mathrm{CO}_{2}\right.$ and $\left.\mathrm{CH}_{4}\right)$, nitrogen $\left(\mathrm{N}_{2} \mathrm{O}\right)$, sulphur $\left(\mathrm{SO}_{2}\right)$ as well as dust. These biogeochemical cycles are crucial for climate mainly because of their role in the atmospheric radiative budget. In turn, climate evolution impacts these cycles by changing their sources and sinks. Past changes are documented in archives such as sediment and ice cores, which have been described in more details in volume 1 . To better understand past changes of the carbon, nitrogen, sulphur and dust cycles and evaluate their impact on climate, they have been included in numerical climate models. Going back and forth between data and model simulations is crucial to unravel the causes of past changes, and in the future, both more data and improved modelling should help to better understand the changes in the biogeochemical cycles over the last million years.

\section{References}

Adams, J. M., Faure, H., Faure-Denard, L., McGlade, J. M. et Woodward, F. I. (1990), Increases in terrestrial carbon storage from the Last Glacial Maximum to the present, Nature, 348, 711-714.

Adkins, J. F., K. McIntyre, and D. P. Schrag (2002), The Salinity, Temperature, and $\delta^{18} \mathrm{O}$ of the Glacial Deep Ocean, Science, 298, 1769-1773, doi: 10.1126/science.1076252.

Adkins, J. F. (2013), The role of deep ocean circulation in setting glacial climates, Paleoceanography, 28, 539-561, doi: 10.1002/palo.20046.

Adloff, F., S. Somot, F. Sevault, G. Jordà, R. Aznar, M. Déqué, M. Herrmann, M. Marcos, C. Dubois, E. Padorno, E. Alvarez-Fanjul, and D. Gomis (2015), Mediterranean Sea response to climate change in an ensemble of twenty first century scenarios, Climate Dynamics, 45(9-10), 2775-2802, doi:10.1007/s00382-015-2507-3.

Ahn, J. and E. J. Brook (2008), Atmospheric $\mathrm{CO}_{2}$ and Climate on Millennial Time Scales During the Last Glacial Period, Science 322, 83, doi: 10.1126/science.1160832. 
Page 34

Ahn, J., E. J. Brook, A. Schmittner, and K. Kreutz (2012), Abrupt change in atmospheric $\mathrm{CO}_{2}$ during the last ice age, Geophys. Res. Lett., 39, L18711, doi: 10.1029/2012GL053018.

Albani, S., Mahowald, N. M., Winckler, G., Anderson, R. F., Bradtmiller, L. I., Delmonte, B., François, R., Goman, M., Heavens, N. G., Hesse, P. P., Hovan, S. A., Kang, S., Kohfeld, K. E., Lu, H., Maggi, V., Mason, J. A., Mayewski, P. A., McGee, D., Miao, X., Otto-Bliesner, B. L., Perry, A. T., Pourmand, A., Roberts, H. M., Rosenbloom, N., Stevens, T., and Sun, J. (2015), Twelve thousand years of dust: The Holocene global dust cycle constrained by natural archives, Clim. Past, 11, 869-903, doi:10.5194/cp-11-869-2015.

Albani, S., Balkanski, Y., Mahowald, N., Winckler, G., Maggi, V., and Delmonte, B. (2018), Aerosol-climate interactions during the Last Glacial Maximum, Current Climate Change Reports, 4, 99-114, doi:10.1007/s40641-018-0100-7.

Anderson, R. F., S. Ali, L. I. Bradtmiller, S. H. H. Nielsen, M. Q. Fleisher, B. E. Anderson, L. H. Burckle (2009), Wind-Driven Upwelling in the Southern Ocean and the Deglacial Rise in Atmospheric $\mathrm{CO}_{2}$, Science, 323, 1443, doi: 10.1126/science.1167441.

Archer, D. and Maier-Reimer, E. (1994), Effect of deep-sea sedimentary calcite preservation on atmospheric $\mathrm{CO}_{2}$ concentration, Nature, 367, 260-263.

Archer, D., Winguth, A., Lea, D. and Mahowald, N. (2000), What caused the glacial / interglacial $\mathrm{pCO}_{2}$ cycles ?, Rev. Geophys., 38,159-189.

Archer, D. E., Martin, P. A., Milovich, J., Brovkin, V., Plattner, G.-K. and Ashendel, C. (2003), Model sensitivity in the effect of Antarctic sea ice and stratification on atmospheric $\mathrm{pCO}_{2}$, Paleoceanography, 18(1), 1012.

Ayache, M., Dutay, J.-C., Arsouze, T., Révillon, S., Beuvier, J., and Jeandel, C. (2016), High resolution neodymium characterization along the Mediterranean margins and modeling of

$\varepsilon N d$ distribution in the Mediterranean basins. Biogeosciences, (April), 1-31, http://doi.org/10.5194/bg-2016-109.

Barker, S., Diz, P., Vautravers, M. J., Pike, J., Knorr, G., Hall, I. R. and Broecker, W. S. (2009), Interhemispheric Atlantic seesaw response during the last deglaciation, Nature, 457, 1097-1102, doi: 10.1038/nature07770.

Barnola, J. M., Raynaud, D., Korotkevich, Y. S. and Lorius, C. (1987), Vostok Ice Core Provides 160,000-Year Record of Atmospheric $\mathrm{CO}_{2}$, Nature, 329, 408-414.

Basak, C., H. Fröllje, F. Lamy, R. Gersonde, V. Benz, R. F. Anderson, M. Molina-Kescher, K. Pahnke (2018), Breakup of last glacial deep stratification in the South Pacific, Science, 359 (6378), 900-904, doi: 10.1126/science.aao2473.

Bereiter, B., D. Lüthi, M. Siegrist, S. Schüpbach, T. F. Stocker, H. Fischer (2012), Mode change of millennial $\mathrm{CO}_{2}$ variability during the last glacial cycle associated with a bipolar marine carbon seesaw, Proceedings of the National Academy of Sciences, 109 (25) 9755-9760; doi: 10.1073/pnas.1204069109.

Bereiter, B., S. Eggleston, J. Schmitt, C. Nehrbass-Ahles, T. F. Stocker, H. Fischer, S. Kipfstuhl, and J. Chappellaz (2015), Revision of the EPICA Dome $\mathrm{C} \mathrm{CO}_{2}$ record from 800 to $600 \mathrm{kyr}$ before present, Geophys. Res. Lett., 42, 542-549, doi:10.1002/2014GL061957.

Berner, R.A., Beerling, D.J., Dudley, R., Robinson, J.M., and Wildman, R.A. (2003), Phanerozoic Atmospheric Oxygen. Annual Review of Earth and Planetary Sciences 31, 105-134.

Bigelow, N. H., Brubaker, L. B., Edwards, M. E., Harrison, S. P., Prentice, I. C., Anderson, P. M., Andreev, A. A., Bartlein, P. J., Christensen, T. R., Cramer, W., Kaplan, J. O., Lozhkin, A. V., Matveyeva, N. V., Murray, D. V., McGuire, A. D., Razzhivin, V. Y., Ritchie, J. C., Smith, B., 
Walker, D. A., Gajewski, K., Wolf, V., Holmqvist, B. H., Igarashi, Y., Kremenetskii, K., Paus, A., Pisaric, M. F. J., and Vokova, V. S. (2003), Climate change and Arctic ecosystems I. Vegetation changes north of $55^{\circ} \mathrm{N}$ between the last glacial maximum, mid-Holocene and present, Journal of Geophysical Research, 108 (D19), 8170.

Bird, M. I., Lloyd, J. et Farquhar, G. D. (1994), Terrestrial carbon storage at the LGM, Nature, 371, 566.

Blunier, T., J. Chappellaz, J. Schwander, A. Dällenbach, B. Stauffer, T. F. Stocker, D. Raynaud, J. Jouzel, H. B. Clausen, C. U. Hammer and S. J. Johnsen (1998), Asynchrony of Antarctic and Greenland climate change during the last glacial period, Nature, 394, 739-743.

Buizert, C., Cuffey, K. M., Severinghaus, J. P., Baggenstos, D., Fudge, T. J., Steig, E. J., Markle, B. R., Winstrup, M., Rhodes, R. H., Brook, E. J., Sowers, T. A., Clow, G. D., Cheng, H., Edwards, R. L., Sigl, M., McConnell, J. R., and Taylor, K. C. (2015), The WAIS Divide deep ice core WD2014 chronology - Part 1: Methane synchronization (68-31 ka BP) and the gas age-ice age difference, Clim. Past, 11, 153-173, https://doi.org/10.5194/cp-11-153-2015.

Bopp, L., Kohfeld, K. E., Quéré, C. L. et Aumont, O. (2003a), Dust impact on marinebiota and atmospheric $\mathrm{CO}_{2}$ during glacial periods, Paleoceanography, 18(2), 1046.

Bopp, L. O. Aumont, S. Belviso and P. Monfray (2003b), Potential impact of climate change on marine dimethyl sulfide emissions, Tellus B: Chemical and Physical Meteorology, 55 (1), 11-22, doi: $10.3402 /$ tellusb.v55i1.16359

Bopp, L. et al. (2013), Multiple stressors of ocean ecosystems in the 21st century: projections with CMIP5 models, Biogeosciences 10, 6225-6245, doi:10.5194/bg-10-6225-2013.

Bopp, L., Resplandy, L., Untersee, A., Mezo, P.L., and Kageyama, M. (2017), Ocean (de)oxygenation from the Last Glacial Maximum to the twenty-first century: insights from Earth System models, Phil. Trans. R. Soc. A, 375, 20160323.

Boucher, O., Randall, D., Artaxo, P., Bretherton, C., Feingold, G., Forster, P., Kerminen, V.-M., Kondo, Y., Liao, H., Lohmann, U., Rasch, P., Satheesh, S. K., Sherwood, S., Stevens, B., and Zhang, X. Y.: Clouds and Aerosols, in: Climate Change 2013: The Phys- ical Science Basis. Contribution of Working Group I to the Fifth Assessment Report of the Intergovernmental Panel on Climate Change edited by: Stocker, T. F., Qin, D., Plattner, G.-K., Tignor, M., Allen, S. K., Boschung, J., Nauels, A., Xia, Y., Bex, V., and Midgley, P. M., Cambridge University Press, Cambridge, UK and New York, NY, USA, 2013.

Bouttes, N., D. M. Roche, and D. Paillard (2009), Impact of strong deep ocean stratification on the glacial carbon cycle, Paleoceanography, 24, PA3203, doi: 10.1029/2008PA001707.

Bouttes, N., D. Paillard and D. M. Roche (2010), Impact of brine-induced stratification on the glacial carbon cycle, Clim. Past, 6, 575-589, doi: 10.5194/cp-6-575-2010.

Bouttes, N., D. Paillard, D. M. Roche, V. Brovkin and L. Bopp (2011), Last Glacial Maximum $\mathrm{CO}_{2}$ and $\delta^{13} \mathrm{C}$ successfully reconciled, Geophys. Res. Lett., 38, L02705, doi:10.1029/2010GL044499.

Bouttes, N., Roche, D., Paillard, D. (2012), Systematic study of the impact of fresh water fluxes on the glacial carbon cycle, Clim. Past, 8, 589-607.

Bouttes, N., Swingedouw, D., Roche, D. M., Sanchez-Goni, M. F., and Crosta, X. (2018), Response of the carbon cycle in an intermediate complexity model to the different climate configurations of the last nine interglacials, Clim. Past, 14, 239-253, https://doi.org/10.5194/cp-14-239-2018.

Bozbiyik, A., Steinacher, M., Joos, F., Stocker, T.F., Menviel, L. (2011), Fingerprints of changes in the terrestrial carbon cycle in response to large reorganizations in ocean circulation, Clim. Past, 7, $319-338$. 
Broecker, W. S. et Peng, T.-H., editors (1982), Tracers in the Sea, Lamont-Doherty Geological Observatory of Columbia University, Palisades, New York.

Brook, E. J., S. Harder, J. Severinghaus, E. J. Steig, and C. M. Sucher (2000), On the origin and timing of rapid changes in atmospheric methane during the Last Glacial Period, Global Biogeochem. Cycles, 14(2), 559-572, doi:10.1029/1999GB001182.

Brovkin, V., Ganopolski, A., Archer, D., and Munhoven, G. (2012), Glacial $\mathrm{CO}_{2}$ cycle as a succession of key physical and biogeochemical processes, Clim. Past, 8, 251-264, https://doi.org/10.5194/cp-8-251-2012.

Carslaw, K.S., Boucher O., Spracklen, D.V., Mann G.W., Rae J.G.L., Woodward S., et al. (2010), A review of natural aerosol interactions and feedbacks within the Earth system, Atmos Chem Phys., 10(4),1701-37.

Catling, D.C., and Claire, M.W. (2005), How Earth's atmosphere evolved to an oxic state: A status report, Earth and Planetary Science Letters, 237, 1-20.

Chappellaz, J., Barnola, J. M., Raynaud, D., Korotkevich, Y. S. and Lorius, C. (1990), Ice-Core Record of Atmospheric Methane over the Past 160,000 Years, Nature, 345, 127-131.

Chappellaz, J. A., Fung, I. Y. and Thompson, A. M. (1993), The Atmospheric $\mathrm{CH}_{4}$ Increase since the Last Glacial Maximum. 1. Source Estimates, Tellus, 45B, 228-241.

Chappellaz, J., Brook, E., Blunier, T. and Malaizé B. (1997), $\mathrm{CH}_{4}$ and $\delta^{18} \mathrm{O}$ of $\mathrm{O}_{2}$ records from Antarctic and Greenland ice: A clue for stratigraphic disturbance in the bottom part of the Greenland Ice Core Project and the Greenland Ice Sheet Project 2 ice cores, J. Geophys. Res., 102, 26547-26557.

Charlson, R. J., J. E. Lovelock, M. O. Andreae and S. G. Warren (1987), Oceanic phytoplankton, atmospheric sulphur, cloud albedo and climate, Nature, 326, 655-661.

Ciais, P., A. Tagliabue, M. Cuntz, L. Bopp, M. Scholze, G. Hoffmann, A. Lourantou, S. P. Harrison, I. C. Prentice, D. I. Kelley, C. Koven and S. L. Piao (2012), Large inert carbon pool in the terrestrial biosphere during the Last Glacial Maximum, Nature Geoscience, 5, 74-79, doi:10.1038/ngeo1324.

Clement, A. C., and L. C. Peterson (2008), Mechanisms of abrupt climate change of the last glacial period, Rev. Geophys., 46, RG4002, doi: 10.1029/2006RG000204.

Craig, H. (1957), Isotopic standards for carbon and oxygen and correction factors for massspectrometric analysis of carbon dioxide, Geochim. Cosmochim. Acta, 12, 133-149.

Crichton, K. A., N. Bouttes, D. R. Roche, J. Chappellaz and G. Krinner (2016), Permafrost carbon as a missing link to explain $\mathrm{CO}_{2}$ changes during the last deglaciation, Nature Geoscience, 9, 683686, doi:10.1038/ngeo2793.

Crowley, T. (1995), Ice age terrestrial carbon changes revisited, Global Biogeochem. Cycles, 9(3), 377-389.

Crutzen, P. J. and C. Brühl (1993), A model study of atmospheric temperatures and the concentrations of ozone, hydroxyl, and some other photochemically active gases during the glacial, the pre-industrial Holocene and the present, Geophys. Res. Lett., 20 (11), 1047-1050.

Curry, W. B. and D. W. Oppo (2005), Glacial water mass geometry and the distribution of $\delta^{13} \mathrm{C}$ of $\Sigma \mathrm{CO}_{2}$ in the western Atlantic Ocean, Paleoceanography, 20, PA1017, doi:10.1029/2004PA001021.

Dahl-Jensen, D. (2018), Drilling for the oldest ice, Nature Geoscience, 11, 703-704. 
Dansgaard, W., S. J. Johnsen, H. B. Clausen, D. Dahl-Jensen, N. S. Gundestrup, C. U. Hammer, C. S. Hvidberg, J. P. Steffensen, A. E. Sveinbjörnsdottir, J. Jouzel and G. Bond (1993), Evidence for general instability of past climate from a 250-kyr ice-core record, Nature, 364, 218-220.

De Boer, A. M., and A. M. C. Hogg (2014), Control of the glacial carbon budget by topographically induced mixing, Geophys. Res. Lett., 41, doi:10.1002/2014GL059963.

Delmas R., Ascencio, J. M. and Legrand, M. (1980), Polar Ice Evidence that Atmospheric $\mathrm{CO}_{2}$ 20,000 Year BP Was 50\% of Present, Nature, 284, 155-157.

Emeis, K.-C., H. Schulz, U. Struck, M. Rossignol-Strick, H. Erlenkeuser, M. W. Howell, D. Kroon, a. Mackensen, S. Ishizuka, T. Oba, T. Sakamoto, and I. Koizumi (2003), Eastern Mediterranean surface water temperatures and $18 \mathrm{O}$ composition during deposition of sapropels in the late Quaternary, Paleoceanography, 18(1), n/a-n/a, doi:10.1029/2000PA000617.

EPICA Community Members (2004), Eight glacial cycles from an Antarctic ice core , Nature, 429 , 623-628 . doi: 10.1038/nature02599.

EPICA Community Members (2006), One-to-one coupling of glacial climate variability in Greenland and Antarctica, Nature, 444 (7116), 195-198, doi: 10.1038/nature05301.

Ezat, M. M., T. L. Rasmussen, B. Hönisch, J. Groeneveld and P. deMenocal (2017), Episodic release of $\mathrm{CO} 2$ from the high-latitude North Atlantic Ocean during the last $135 \mathrm{kyr}$, Nature Communications, 8, 14498.

Ferrari, R., M. F. Jansen, J. F. Adkins, A. Burke, A. L. Stewart, and A. F. Thompson (2014), Antarctic sea ice control on ocean circulation in present and glacial climates, PNAS, 111 (24), 8753-8758, doi: 10.1073/pnas.1323922111.

Fischer, H., Schmitt, J., Lüthi, D., Stocker, T.F., Tschumi, T., Parekh, P., Joos, F., Köhler, P., Völker, C., Gersonde, R., Barbante, C., Le Floch, M., Raynaud, D., Wolff, E. (2010), The role of Southern Ocean processes on orbital and millennial $\mathrm{CO}_{2}$ variations - a synthesis, Quaternary Science Reviews, 29(1-2), 193-205, doi:10.1016/j.quascirev.2009.06.007.

Flückiger, J., T. Blunier, B. Stauffer, J. Chappellaz, R. Spahni, K. Kawamura, J. Schwander, T. F. Stocker, and D. Dahl-Jensen (2004), $\mathrm{N}_{2} \mathrm{O}$ and $\mathrm{CH}_{4}$ variations during the last glacial epoch: Insight into global processes, Global Biogeochem. Cycles, 18, GB1020, doi:10.1029/2003GB002122.

Garcia, H. E., R. A. Locarnini, T. P. Boyer, J. I. Antonov, O. K. Baranova, M. M. Zweng, and D. R. Johnson, 2010. World Ocean Atlas 2009, Volume 3: Dissolved Oxygen, Apparent Oxygen Utilization, and Oxygen Saturation. S. Levitus, Ed. NOAA Atlas NESDIS 70, U.S. Government Printing Office, Washington, D.C., 344 pp.

Gersonde R., Crosta X., Abelmann A. and L. Armand (2005), Sea-surface temperature and sea ice distribution of the Southern Ocean at the EPILOG Last Glacial Maximum - a circum-Antarctic view based on siliceous microfossil records, Quat. Sci. Rev., 24, 869-896.

Goosse, H., D. M. Roche, A. Mairesse, M. Berger (2013), Modeling past sea ice changes, Quaternary Science Reviews, 79, 191-206, doi:10.1016/j.quascirev.2013.03.011.

Gottschalk, J., L. C. Skinner, J. Lippold, H. Vogel, N. Frank, S. L. Jaccard and C. Waelbroeck (2016), Biological and physical controls in the Southern Ocean on past millennial-scale atmospheric $\mathrm{CO}_{2}$ changes, Nature Communications, 7, 11539.

Grant, K.M., Rohling, E.J., Bar-Matthews, M., Ayalon, A., Medina-Elizalde, M., Bronk Ramsey, C., Satow, C., Roberts, A.P. (2012), Rapid coupling between ice volume and polar temperature over the past 150 kyr. Nature 491, 744-747.

Grimm, R., E. Maier-Reimer, U. Mikolajewicz, G. Schmiedl, K. Müller-Navarra, F. Adloff, K. M.

Grant, M. Ziegler, L. J. Lourens, and K.-C. Emeis (2015), Late glacial initiation of Holocene 
Page 38

eastern Mediterranean sapropel formation, Nature Communications, 6(7099),12pp, doi:10.1038/ncomms8099.

Hamon, N., P. Sepulchre, V. Lefebvre, and G. Ramstein (2013), The role of eastern Tethys seaway closure in the Middle Miocene Climatic Transition (ca. 14 Ma), Climate of the Past, 9(6), 2687-2702, doi:10.5194/cp-9-2687-2013.

Harrison, S. P., Yu, G., Takahara, H., and Prentice, I. C. (2001), Palaeovegetation - Diversity of temperate plants in east Asia, Nature, 413, 129-130.

Hemleben, Ch., Hoernle, K., Jørgensen, B.B., Roether, W., 2003. Ostatlantik-Mittelmeer-

Schwarzes Meer, Cruise 51, 12 September-28 December 2001. Meteor Ber. 03-1 (213 pp.)

Hemming, S. R. (2004), Heinrich events: Massive late Pleistocene detritus layers of the North Atlantic and their global climate imprint, Rev. Geophys., 42, RG1005,

doi:10.1029/2003RG000128.

Heinrich, H. (1988), Origin and consequences of cyclic ice rafting in the Northeast Atlantic Ocean during the past 130,000 years, Quaternary Research, 29 (2), 142-152, https://doi.org/10.1016/00335894(88)90057-9.

Hesse, T., M. Butzin, T. Bickert, and G. Lohmann (2011), A model-data comparison of $\delta^{13} \mathrm{C}$ in the glacial Atlantic Ocean, Paleoceanography, 26, PA3220, doi:10.1029/2010PA002085.

Holland, H. D. in Early Life on Earth (ed. Bengston, S.) 237-244 (Columbia Univ. Press, New York, 1994).

Jaccard, S.L., and Galbraith, E.D. (2011). Large climate-driven changes of oceanic oxygen concentrations during the last deglaciation. Nature Geoscience 5, 151-156.

Jaccard, S. L. and E. D. Galbraith (2012), Large climate-driven changes of oceanic oxygen concentrations during the last deglaciation, Nature Geoscience, 5, 151-156.

Jaccard, S., Galbraith, E., Frölicher, T., and Gruber, N. (2014). Ocean (De)oxygenation Across the Last Deglaciation: Insights for the Future. Oceanography 27, 26-35.

Jickells TD, An ZS, Andersen KK, Baker AR, Bergametti G, Brooks N, Cao JJ, Boyd PW, Duce RA, Hunter KA, Kawahata H, Kubilay N, LaRoche J, Liss PS, Mahowald NM, Prospero JM, Ridgwell AJ, Tegen I, Torres R (2005), Global iron connections between desert dust, ocean biogeochemistry, and climate, Science, 308:67, doi:10.1126/science.1105959.

Jouzel, J., V. Masson-Delmotte, O. Cattani, G. Dreyfus, S. Falourd, G. Hoffmann, B. Minster, J. Nouet, J.M. Barnola, J. Chappellaz, H. Fischer, J.C. Gallet, S. Johnsen, M. Leuenberger, L. Loulergue, D. Luethi, H. Oerter, F. Parrenin, G. Raisbeck, D. Raynaud, A. Schilt, J. Schwander, E. Selmo, R. Souchez, R. Spahni, B. Stauffer, J.P. Steffensen, B. Stenni, T.F. Stocker, J.L. Tison, M. Werner, and E.W. Wolff (2007), Orbital and Millennial Antarctic Climate Variability over the Past 800,000 Years, Science, 317 (5839), 793-797.

Kaplan, J. O., G. Folberth, and D. A. Hauglustaine (2006), Role of methane and biogenic volatile organic compound sources in late glacial and Holocene fluctuations of atmospheric methane concentrations, Global Biogeochem. Cycles, 20, GB2016, doi:10.1029/2005GB002590.

Kohfeld, K. E., and S. P. Harrison (2001), DIRTMAP: The geological record of dust, Earth Sci. Rev., 54, 81-114, doi:10.1016/S0012-8252(01)00042-3.

Kohfeld, K. E., Quéré, C. L., Harrison, S. P. et Anderson, R. F. (2005), Role of Marine Biology in Glacial-Interglacial $\mathrm{CO}_{2}$ Cycles, Science, 308, 74-78.

Kohfeld, K.E., R.M. Graham, A.M. de Boer, L.C. Sime, E.W. Wolff, C. Le Quéré, L. Bopp (2013), Southern Hemisphere westerly wind changes during the Last Glacial Maximum: paleo-data synthesis, Quaternary Science Reviews, 68, 76-95, https://doi.org/10.1016/j.quascirev.2013.01.017. 
Köhler, P., G. Knorr and E. Bard (2014), Permafrost thawing as a possible source of abrupt carbon release at the onset of the Bølling/Allerød, Nature Communications, doi: 10.1038/ncomms6520.

Köng, E., Zaragosi, S., Schneider, J. L., Garlan, T., Bachèlery, P., Sabine, M., and San Pedro, L. (2017), Gravity-Driven Deposits in an Active Margin (Ionian Sea) Over the Last 330,000 Years. Geochemistry, Geophysics, Geosystems, 18(11), 4186-4210.

http://doi.org/10.1002/2017GC006950.

Kullenberg, B. (1952), On the salinity of the water contained in marine sediments, Medd. Oceanogr. Inst. Göteb. 21, 1-38.

Lambert, F., A. Tagliabue, G. Shaffer, F. Lamy, G. Winckler, L. Farias, L. Gallardo, and R. De PolHolz (2015), Dust fluxes and iron fertilization in Holocene and Last Glacial Maximum climates, Geophys. Res. Lett., 42, 6014-6023, doi:10.1002/ 2015GL064250.

Landais, A., G. Dreyfus, E. Capron, J. Jouzel, V. Masson-Delmotte, D. M. Roche, F. Prié, N. Caillon, J. Chappellaz, M. Leuenberger, A. Lourantou, F. Parrenin, D. Raynaud and G. Teste (2013), Two-phase change in $\mathrm{CO}_{2}$, Antarctic temperature and global climate during Termination II, Nature Geoscience, 6, 1062-1065, doi: 10.1038/NGEO1985.

Legrand, M., C. Feniet-Saigne, E. S. Sattzman, C. Germain, N. I. Barkov and V. N. Petrov, Ice-core record of oceanic emissions of dimethylsulphide during the last climate cycle, Nature, 350, 144-146 (1991).

Legrand M, Mayewski P. (1997), Glaciochemistry of polar ice cores: a review. Rev Geophys., 35(3):219-43.

Levine, J. G., E. W. Wolff, A. E. Jones, L. C. Sime, P. J. Valdes, A. T. Archibald, G. D. Carver, N. J. Warwick, and J. A. Pyle (2011), Reconciling the changes in atmospheric methane sources and sinks between the Last Glacial Maximum and the pre-industrial era, Geophys. Res. Lett., 38, L23804, doi:10.1029/2011GL049545.

Loulergue, L., A. Schilt, R. Spahni, V. Masson-Delmotte, T. Blunier, B. Lemieux, J.-M. Barnola, D. Raynaud, T.F. Stocker, and J. Chappellaz (2008), Orbital and millennial-scale features of atmospheric $\mathrm{CH}_{4}$ over the past 800,000 years, Nature, 453, 383-386, doi:10.1038/nature06950.

Lüthi, D., M. Le Floch, B. Bereiter, T. Blunier, J.-M. Barnola, U. Siegenthaler, D. Raynaud, J. Jouzel, H. Fischer, K. Kawamura and T. F. Stocker (2008), High-resolution carbon dioxide concentration record 650,000-800,000 years before present, Nature, 453, 379-382, doi:10.1038/nature06949.

Lourantou, A., J. V. Lavrič, P. Köhler, J.-M. Barnola, D. Paillard, E. Michel, D. Raynaud, and J. Chappellaz (2010), Constraint of the $\mathrm{CO}_{2}$ rise by new atmospheric carbon isotopic measurements during the last deglaciation, Global Biogeochem. Cycles, 24, GB2015, doi:10.1029/2009GB003545.

Mahowald NM, Scanza R, Brahney J, Goodale CL, Hess PG, Moore JK, et al. (2017), Aerosol deposition impacts on land and ocean carbon cycles, Current Climate Change Reports, 3(1), 16-31.

Marcott, S. A., T. K. Bauska, C. Buizert, E. J. Steig, J. L. Rosen, K. M. Cuffey, T. J. Fudge, J. P. Severinghaus, J. Ahn, M. L. Kalk, J. R. McConnell, T. Sowers, K. C. Taylor, J. W. C. White and E. J. Brook (2014), Centennial-scale changes in the global carbon cycle during the last deglaciation, Nature, 514, 616-619, doi:10.1038/nature13799.

Mariotti, V. (2013), Le cycle du carbone en climat glaciaire : état moyen et variabilité, 252 pages, $\mathrm{PhD}$ thesis.

Marchal, O. and W.B. Curry (2008), On the Abyssal Circulation in the Glacial Atlantic, J. Phys. Oceanogr., 38, 2014-2037, https://doi.org/10.1175/2008JPO3895.1. 
Martinez-Ruiz, F., M. Kastner, A. Paytan, M. Ortega-Huertas, and S. Bernasconi (2000), Geochemical evidence for enhanced productivity during S1 sapropel deposition in the eastern Mediterranean, Paleoceanography, 15(2), 200-209, doi:10.1029/1999PA000419.

Marzocchi, A., and M. F. Jansen (2017), Connecting Antarctic sea ice to deep-ocean circulation in modern and glacial climate simulations, Geophys. Res. Lett., 44, 6286-6295, doi:10.1002/2017GL073936.

Maslin, M., Adams, J., Thomas, E., Faure, H. et Haines-Young, R. (1995), Estimating the carbon transfer between the ocean, atmosphere and the terrestrial biosphere since the last glacial maximum. Terra Nova, 7 (3),358-366.

Matsumoto, K., Yokoyama, Y. (2013), Atmospheric $\Delta{ }^{14} \mathrm{C}$ reduction in simulations of Atlantic overturning circulation shutdown, Glob. Biogeochem. Cycles, 27, http:// dx.doi.org/10.1002/gbc.20035.

Menviel, L., Timmermann, A., Mouchet, A. et Timm, O. (2008a), Climate and marine carbon cycle response to changes in the strength of the Southern Hemispheric westerlies, Paleoceanography, 23, PA4201.

Menviel, L., A. Timmermann, A. Mouchet, and O. Timm (2008b), Meridional reorganizations of marine and terrestrial productivity during Heinrich events, Paleoceanography, 23, PA1203, doi: 10.1029/2007PA001445.

Menviel, L., P. Spence, M.H. England (2015), Contribution of enhanced Antarctic Bottom Water formation to Antarctic warm events and millennial-scale atmospheric $\mathrm{CO}_{2}$ increase, Earth and Planetary Science Letters, 413, 37-50, https://doi.org/10.1016/j.epsl.2014.12.050.

Menviel, L., J. Yu, F. Joos, A. Mouchet, K. J. Meissner, and M. H. England (2017), Poorly ventilated deep ocean at the Last Glacial Maximum inferred from carbon isotopes: A data-model comparison study, Paleoceanography, 32, 2-17, doi:10.1002/2016PA003024.

Milkov, A., V., Global estimates of hydrate-bound gas in marine sediments: how much is really out there? (2004), Earth-Science Reviews, 66 (3-4), 183-197, https://doi.org/10.1016/j.earscirev.2003.11.002.

Möbius, J., Lahajnar, N., \& Emeis, K. C. (2010), Diagenetic control of nitrogen isotope ratios in Holocene sapropels and recent sediments from the Eastern Mediterranean Sea, Biogeosciences, 7(11), 3901-3914. http://doi.org/10.5194/bg-7-3901-2010.

Muglia, J., and A. Schmittner (2015), Glacial Atlantic overturning increased by wind stress in climate models, Geophys. Res. Lett., 42, doi:10.1002/2015GL064583.

Murray, L. T., Mickley, L. J., Kaplan, J. O., Sofen, E. D., Pfeiffer, M., and Alexander, B.( 2014), Factors controlling variability in the oxidative capacity of the troposphere since the Last Glacial Maximum, Atmos. Chem. Phys., 14, 3589-3622, https://doi.org/10.5194/acp-14-3589-2014.

NEEM community members (2013), Eemian interglacial reconstructed from a Greenland folded ice core, Nature,493, 489-494, doi:10.1038/nature11789

Nijenhuis, I.A., De Lange, G.J. (2000), Geochemical constraints on Pliocene sapropel formation in the eastern Mediterranean. Mar. Geol. 163, 41-63.

North Greenland Ice Core Project members (2004), High-resolution record of Northern Hemisphere climate extending into the last interglacial period, Nature, 431, 147-151.

Obata, A. (2007), Climate-carbon cycle model response to freshwater discharge into the North Atlantic, J. Climate, 20, 5962-5976, https://doi.org/10.1175/2007JCLI1808.1.

O’Dowd CD, de Leeuw G. (2007), Marine aerosol production: a review of the current knowledge. Philos Trans R Soc A Math Phys Eng Sci., 365(1856):1753-74. 
Parrenin, F., V. Masson-Delmotte, P. Köhler, D. Raynaud, D. Paillard, J. Schwander, C. Barbante, A. Landais, A. Wegner, J. Jouzel, Synchronous Change of Atmospheric $\mathrm{CO}_{2}$ and Antarctic Temperature During the Last Deglacial Warming (2013), Science, 339, 1060, doi: $10.1126 /$ science. 1226368 .

Petit, J. R., Jouzel, J., Raynaud, D., Barkov, N. I., Barnola, J. M., Basile, I., Bender, M., Chappellaz, J., Davis, M., Delaygue, G., Delmotte, M., Kotlyakov, V. M., Legrand, M., Lipenkov, V. Y., Lorius, C., Pepin, L., Ritz, C., Saltzman, E. and Stievenard, M. (1999), Climate and Atmospheric History of the Past 420000 Years from the Vostok Ice Core, Antarctica, Nature, 399, 429-436.

Pickett, E. J., Harrison, S. P., Hope, G. , Harle, K. , Dodson, J. R., Peter Kershaw, A. , Colin Prentice, I. , Backhouse, J. , Colhoun, E. A., D'Costa, D. , Flenley, J. , Grindrod, J. , Haberle, S. , Hassell, C. , Kenyon, C. , Macphail, M. , Martin, H. , Martin, A. H., McKenzie, M. , Newsome, J. C., Penny, D. , Powell, J. , Ian Raine, J., Southern, W. , Stevenson, J., Sutra, J., Thomas, I. , Kaars, S. and Ward, J. (2004), Pollen-based reconstructions of biome distributions for Australia, Southeast Asia and the Pacific (SEAPAC region) at 0, 6000 and 18,000 14C yr BP. Journal of Biogeography, 31: 1381-1444. doi:10.1111/j.1365-2699.2004.01001.x

Plancq, J., Grossi, V., Pittet, B., Huguet, C., Rosell-Melé, A., \& Mattioli, E. (2015), Multi-proxy constraints on sapropel formation during the late Pliocene of central Mediterranean (southwest Sicily), Earth and Planetary Science Letters, 420, 30-44.

Prather, M. J., Lifetimes and time scales in atmospheric chemistry (2007), 365, Philosophical Transactions of the Royal Society A: Mathematical, Physical and Engineering Sciences, http://doi.org/10.1098/rsta.2007.2040

Prentice, I. C., Jolly, D., and BIOME 6000 Participants. (2000), Mid-Holocene and glacialmaximum vegetation geography of the northern continents and Africa, Journal of Biogeography 27, 507-519.

Preunkert, S., M. Legrand, B. Jourdain, C. Moulin, S. Belviso, N. Kasamatsu, M. Fukuchi, and T. Hirawake (2007), Interannual variability of dimethylsulfide in air and seawater and its atmospheric oxidation by-products (methanesulfonate and sulfate) at Dumont d'Urville, coastal Antarctica (1999-2003), J. Geophys. Res., 112, D06306, doi:10.1029/2006JD007585.

Preunkert S, Legrand M. (2013), Towards a quasi-complete reconstruction of past atmospheric aerosol load and composition (organic and inorganic) over Europe since 1920 inferred from Alpine ice cores, Clim Past., 9(4),1403-16.

Quiquet, A., A.T. Archibald, A.D. Friend, J. Chappellaz, J.G. Levine, E.J. Stone, P.J. Telford, J.A. Pyle (2015), The relative importance of methane sources and sinks over the Last Interglacial period and into the last glaciation, Quaternary Science Reviews, 112, 1-16, https://doi.org/10.1016/j.quascirev.2015.01.004.

Rasmussen, S. O., Bigler, M., Blockley, S. P., Blunier, T., Buchardt, S. L., Clausen, H. B., Cvijanovic, I., Dahl-Jensen, D., Johnsen, S. J., Fischer, H., Gkinis, V., Guillevic, M., Hoek, W. Z., Lowe, J. J., Pedro, J. B., Popp, T., Seierstad, I. K., Steffensen, J. P., Svensson, A. M., Vallelonga, P., Vinther, B. M., Walker, M. J., Wheatley, J. J., and Winstrup, M.: A stratigraphic framework for abrupt climatic changes during the Last Glacial period based on three synchronized Greenland icecore records: refining and ex- tending the INTIMATE event stratigraphy, Quaternary Sci. Rev., 106, 14-28, 2014.

Rhein M et al. 2013 Observations: ocean. In Climate Change 2013: The Physical Science Basis. Contribution of Working Group I to the Fifth Assessment Report of the Intergovernmental Panel on Climate Change (eds TF Stocker et al.), pp. 255-310. Cambridge, UK: Cambridge University Press. 
Roche, D. M., X. Crosta, H. Renssen (2012), Evaluating Southern Ocean sea ice for the Last Glacial Maximum and pre-industrial climates: PMIP-2 models and data evidences, Quaternary Science Reviews 56 99-106. doi:10.1016/j.quascirev.2012.09.020.

Rogerson, M., Cacho, I., Jimenez-Espejo, F., Reguera, M.I., Sierro, F.J., Martinez-Ruiz, F., Frigola, J., Canals, M. (2008), A dynamic explanation for the origin of the western Mediterranean organic rich layers. Geochem. Geophys. Geosyst. 9, Q07U01. http://dx.doi. org/10.1029/2007GC001936.

Rohling, E.J., Marino, G., Grant, K.M. (2015), Mediterranean climate and oceanography, and the periodic development of anoxic events (sapropels) Earth-Science Reviews 143 (2015) 62-97.

Rosen, J. L., E. J. Brook, J. P. Severinghaus, T. Blunier, L. E. Mitchell, J. E. Lee, J. S. Edwards and V. Gkinis (2014), An ice core record of near-synchronous global climate changes at the Bølling transition, Nature Geoscience, 7, 459-463.

Rossignol-Strick, M., Nesteroff, V., Olive, P., Vergnaud-Grazzini, C. (1982), After the deluge; Mediterranean stagnation and sapropel formation. Nature 295, 105-110.

Saigne, C. and M. Legrand (1987), Measurements of methanesulphonic acid in Antarctic ice, Nature, 330, 240-242.

Schilt, A., M. Baumgartner, T. Blunier, J. Schwander, R. Spahni, H. Fischer, T. F. Stocker (2010), Glacial-interglacial and millennial-scale variations in the atmospheric nitrous oxide concentration during the last 800,000 years, Quaternary Science Reviews, 29, 182-192.

Schilt A., M. Baumgartner, O. Eicher, J. Chappellaz, J. Schwander, H. Fischer, and T. F. Stocker (2013), The response of atmospheric nitrous oxide to climate variations during the last glacial period, Geophys. Res. Lett., 40, 1888-1893, doi:10.1002/grl.50380.

Schmitt, J., R. Schneider, J. Elsig, D. Leuenberger, A. Lourantou, J. Chappellaz, P. Köhler, F. Joos, 1 T. F. Stocker, M. Leuenberger, H. Fischer (2012), Carbon Isotope Constraints on the Deglacial $\mathrm{CO}_{2}$ Rise from Ice Cores, Science, 336, 711, doi: 10.1126/science.1217161.

Schmittner A, Galbraith E D (2008), Glacial greenhouse-gas fluctuations controlled by ocean circulation changes, Nature, 456 (7220), 373-6, doi: 10.1038/nature07531.

Schneider, R., Schmitt, J., Köhler, P., Joos, F., and Fischer, H. (2013), A reconstruction of atmospheric carbon dioxide and its stable carbon isotopic composition from the penultimate glacial maximum to the last glacial inception, Clim. Past, 9, 2507-2523, https://doi.org/10.5194/cp-9-25072013.

Schwander, J. and Stauffer, B. (1984), Age difference between polar ice and the air trapped in its bubbles, Nature, 311, 45-47.

Shackleton, N. J. (1977), Carbon-13 in Uvegerina: Tropical rainforest history and the equatorial Pacific carbonate dissolution cycles, The Fate of Fossil Fuel CO2 in the oceans, edited by N. R. Andersen and A. Malako, 401-428, Plenum, New_York.

Siegenthaler U, Stocker TF, Monnin E, Lüthi D, Schwander J, Stauffer B, Raynaud D, Barnola JM, Fischer H, Masson-Delmotte V, Jouzel J. (2005), Stable carbon cycle-climate relationship during the Late Pleistocene, Science, 310 (5752), 1313-1317, doi:10.1126/science.1120130.

Sigman, D. M. and Boyle, E. A. (2000), Glacial/interglacial variations in atmospheric carbon dioxide, Nature, 407, 859-869.

Skinner, L. C., S. Fallon, C. Waelbroeck, E. Michel, S. Barker (2010), Ventilation of the Deep Southern Ocean and Deglacial $\mathrm{CO}_{2}$ Rise, Science, 328 (5982), 1147 - 1151, doi:

10.1126/science. 1183627. 
Skinner, L. C. (2009), Glacial-interglacial atmospheric $\mathrm{CO}_{2}$ change: a possible "standing volume" effect on deep-ocean carbon sequestration, Clim. Past, 5, 537-550, https://doi.org/10.5194/cp-5537-2009.

Sowers, T., Richard B. Alley (2003), J. Jubenville, Ice Core Records of Atmospheric $\mathrm{N}_{2} \mathrm{O}$ Covering the Last 106,000 Years, Science, 301, 945-948.

Stephens, B. B. et Keeling, R. F. (2000), The influence of Antarctic sea ice on glacial-interglacial $\mathrm{CO}_{2}$ variations, Nature, 404, 171-174.

Stramma, L., Prince, E.D., Schmidtko, S., Luo, J., Hoolihan, J.P., Visbeck, M., Wallace, D.W.R., Brandt, P., and Körtzinger, A. (2012), Expansion of oxygen minimum zones may reduce available habitat for tropical pelagic fishes, Nature Clim. Change, 2, 33-37.

Spahni, R., J. Chappellaz, T. F. Stocker, L. Loulergue, G. Hausammann, K. Kawamura, J.

Flückiger, J. Schwander, D. Raynaud, V. Masson-Delmotte, J. Jouzel (2005), Atmospheric Methane and Nitrous Oxide of the Late Pleistocene from Antarctic Ice Cores, Science, 310, 1317-1321.

Stocker, T. F., and S. J. Johnsen (2003), A minimum thermodynamic model for the bipolar seesaw, Paleoceanography, 18(4), 1087, doi:10.1029/2003PA000920.

Tagliabue, A., Bopp, L., Roche, D. M., Bouttes, N., Dutay, J.-C., Alkama, R., Kageyama, M., Michel, E., and Paillard, D. (2009), Quantifying the roles of ocean circulation and biogeochemistry in governing ocean carbon-13 and atmospheric carbon dioxide at the last glacial maximum, Clim. Past, 5, 695-706.

Tarnocai, C., J. G. Canadell, E. A. G. Schuur, P. Kuhry, G. Mazhitova, and S. Zimov (2009), Soil organic carbon pools in the northern circumpolar permafrost region, Global Biogeochem. Cycles, 23, GB2023, doi:10.1029/2008GB003327.

Toggweiler, J. R., Russell, J. L. et Carson, S. R. (2006), Midlatitude westerlies, atmospheric $\mathrm{CO}_{2}$, and climate change during the ice ages. Paleoceanography, 21, PA2005.

Tschumi, J., and Stauffer, B. (2000), Reconstructing past atmospheric $\mathrm{CO}_{2}$ concentration based on ice-core analyses: Open questions due to in situ production of $\mathrm{CO}_{2}$ in the ice, Journal of Glaciology, 46(152), 45-53, doi:10.3189/172756500781833359.

Tschumi, T., Joos, F., Gehlen, M., and Heinze, C. (2011), Deep ocean ventilation, carbon isotopes, marine sedimentation and the deglacial $\mathrm{CO}_{2}$ rise, Clim. Past, 7, 771-800, https://doi.org/10.5194/cp7-771-2011.

Vadsaria, T., Ramstein, G., Dutay, J. -C., Li, L., Ayache, M., \& Richon, C. (2019), Simulating the occurrence of the last sapropel event (S1): Mediterranean basin ocean dynamics simulations using $\mathrm{Nd}$ isotopic composition modeling. Paleoceanography and Paleoclimatology, http://doi.org/10.1029/2019PA003566

Valdes, P. J., D. J. Beerling, and C. E. Johnson (2005), The ice age methane budget, Geophys. Res. Lett., 32, L02704, doi: 10.1029/2004GL021004.

WAIS Divide Project Members (2015), Precise interpolar phasing of abrupt climate change during the last ice age, Nature, 520, 661-668, doi:10.1038/nature14401.

Walker, J.C.G. (1980), The Oxygen Cycle, In The Natural Environment and the Biogeochemical Cycles, O. Hutzinger, ed. (Berlin, Heidelberg: Springer Berlin Heidelberg), pp. 87-104.

Wang, W., Y. Yung, A. Lacis, T. MO, and J. Hansen (1976), Greenhouse effects due to man made perturbations of trace gases, Science, 194 (4266), 685-690.

Weber, S. L., A. J. Drury, W. H. J. Toonen, and M. van Weele (2010), Wetland methane emissions during the Last Glacial Maximum estimated from PMIP2 simulations: Climate, vegetation, and geographic controls, J. Geophys. Res., 115, D06111, doi:10.1029/2009JD012110. 
Page 44

Wolff, E.W., H. Fischer, F. Fundel, U. Ruth, B. Twarloh, G. C. Littot, R. Mulvaney, R.

Röthlisberger, M. de Angelis, C. F. Boutron, M. Hansson, U. Jonsell, M. A. Hutterli, F. Lambert, P. Kaufmann, B. Stauffer, T. F. Stocker, J. P. Steffensen, M. Bigler, M. L. Siggaard-Andersen, R. Udisti, S. Becagli, E. Castellano, M. Severi, D. Wagenbach, C. Barbante, P. Gabrielli and V. Gaspari (2006), Southern Ocean sea-ice extent, productivity and iron flux over the past eight glacial cycles, Nature 440:23. doi:10.1038/nature04614.

Yin, Q. Z. and A. Berger (2010), Insolation and $\mathrm{CO}_{2}$ contribution to the interglacial climate before and after the Mid-Brunhes Event, Nature Geoscience, 3, 243 - 246, doi:10.1038/ngeo771.

Yin, Q. Z. and A. Berger (2012), Individual contribution of insolation and $\mathrm{CO}_{2}$ to the interglacial climates of the past 800,000 years, Clim. Dynam., 38 (3-4), 709-724.

Yu, J., L. Menviel, Z. D. Jin, D. J. R. Thornalley, S. Barker, G. Marino, E. J. Rohling, Y. Cai, Zhang, F., X. Wang, Y. Dai, P. Chen and W. S. Broecker (2016), Sequestration of carbon in the deep Atlantic during the last glaciation, Nature Geoscience, 9, 319-324.

Ziegler, M., Tuenter, E., Lourens, L.J. (2010), The precession phase of the boreal summer monsoon as viewed from the eastern Mediterranean (ODP Site 968). Quat. Sci. Rev. 29, 1481-1490. 